\title{
Resolution of spontaneous bleeding events but failure of pregnancy in fibrinogen-deficient mice
}

\author{
Theodore T. Suh, ${ }^{1}$ Kenn Holmbäck, ${ }^{1}$ Nancy J. Jensen, ${ }^{1}$ Cynthia C. Daugherty, ${ }^{2}$ Kersten Small, ${ }^{1,3}$ \\ Daniel I. Simon, ${ }^{4}$ S. Steven Potter, ${ }^{1}$ and Jay L. Degen ${ }^{1,5}$ \\ Divisions of 'Basic Science Research and 2Pathology, Children's Hospital Research Foundation, Cincinnati, Ohio 45229 \\ USA; ${ }^{4}$ Cardiovascular Division, Brigham and Women's Hospital, Boston, Massachusetts 02115 USA
}

\begin{abstract}
To explore the role of the key coagulation factor, fibrinogen, in development, hemostasis, wound repair, and

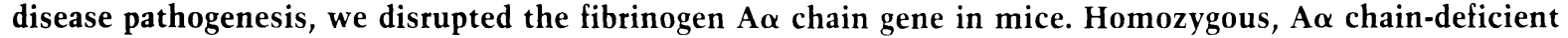
$\left(A \alpha^{-1-}\right)$ mice are born normal in appearance, and there is no evidence of fetal loss of these animals based on the Mendelian pattern of transmission of the mutant A $\alpha$ chain allele. All of the component chains of fibrinogen $(A \alpha, B \beta$, and $\gamma)$ are immunologically undetectable in the circulation of both neonatal and adult $A \alpha^{-1-}$ mice, and blood samples fail to either clot or support platelet aggregation in vitro. Overt bleeding events develop shortly after birth in $\sim 30 \%$ of $\mathrm{A \alpha}^{-1-}$ mice, most frequently in the peritoneal cavity, skin, and soft tissues around joints. Remarkably, most newborns displaying signs of bleeding ultimately control the loss of blood, clear the affected tissues, and survive the neonatal period. Juveniles and young adult $\mathrm{A \alpha}^{-1-}$ mice are predisposed to spontaneous fatal abdominal hemorrhage, but long-term survival is variable and highly dependent on genetic background. The periodic rupture of ovarian follicles in breeding-age A $\alpha^{-1-}$ females does not appear to significantly diminish life expectancy relative to males; however, pregnancy uniformly results in fatal uterine bleeding around the tenth day of gestation. Microscopic analysis of spontaneous lesions found in $\mathrm{A \alpha}^{-1-}$ mice suggests that fibrin(ogen) plays a fundamental role in the organization of cells at sites of injury.
\end{abstract}

[Key Words: Fibrinogen-deficient mice; coagulation; hemostasis; afibrinogenemia; platelet aggregation; wound healing; development]

Received May 15, 1995; revised version accepted June 28, 1995.

Fibrin(ogen) is the ultimate target of two sophisticated and opposing regulatory systems, the coagulation and fibrinolytic cascades, that together preserve vascular integrity and maintain hemostatic balance (Davie et al. 1991; Esmon 1993; Collen and Lijnen 1994). The coagulation system includes more than a dozen soluble and cell-associated factors that initiate, promote, and ultimately limit the formation of insoluble fibrin polymer (Davie et al. 1991). A key step in coagulation is the generation of the serine protease, thrombin, which triggers platelet activation (Majerus 1994), converts fibrinogen into a spontaneously polymerizing fibrin monomer (Doolittle 1994), activates the transglutaminase (factor XIII) that covalently cross-links fibrin matrices (Chung and Ichinose 1995), and activates regulatory pathways that both promote and suppress coagulation (Davie et al. 1991; Dahlbäck and Stenflo 1994). Fibrinogen is fundamentally important in hemostasis in that it constitutes

${ }^{3}$ Present address: Howard Hughes Medical Institute, Emory University, Atlanta, Georgia 30322 USA.

${ }^{5}$ Corresponding author. the primary building block of blood clots. In addition, as a symmetrical dimer $\left(A \alpha_{2} B \beta_{2} \gamma_{2}\right)$ carrying multiple specific binding motifs for the platelet integrin GPIIb-IIIa $\left\langle\alpha_{I I b} \beta_{3}\right\rangle$, fibrinogen serves as the primary bridging molecule linking adjacent activated platelets in platelet plug formation (Bennett 1991). A counterbalancing fibrinolytic system, which includes the fibrin-binding proteins, plasminogen, plasminogen activator, and $\alpha_{2}$-antiplasmin, provides a means for the timely disposal of fibrin clots (Collen and Lijnen 1994). The importance of understanding the biochemical events that lead to the formation and ultimate dissolution of fibrin-rich hemostatic plugs is underscored by the fact that the inauspicious formation of a fibrin clot in a coronary or cerebral artery is a major cause of morbidity and death worldwide. Furthermore, spontaneous and frequently catastrophic hemorrhage or thrombosis is associated with many congenital and acquired disorders in the coagulation and fibrinolytic systems (Collen and Lijnen 1994; Dahlbäck and Stenflo 1994; Doolittle 1994; Marder et al. 1994; Sadler and Davie 1994).

Interestingly, there is considerable evidence that fi- 
brin(ogen) may play a much broader physiological role than simply stemming the loss of blood. First, a variety of cell types specifically bind to and migrate on fibrin/ogen) matrices, including endothelial cells (Dejana et al. 1985), macrophages (Sherman and Lee 1977; Altieri et al. 1986), leukocytes (Wright et al. 1983; Altieri et al. 1993), smooth muscle cells (Naito et al. 1992), fibroblasts (Brown et al. 1993), keratinocytes (Donaldson et al. 1994), and tumor cells (Dvorak 1986; Dvorak et al. 1992). Direct binding to fibrin(ogen) through both integrin [e.g., $\alpha_{v} \beta_{3}, \alpha_{M} \beta_{2}$ (Mac-1); Altieri et al. 1993, Simon et al. 1993; Katagiri et al. 1995] and non-integrin receptors (e.g., I-CAM-1; Languino et al. 1995) appears to contribute to these cell-fibrin interactions. Second, defective and delayed wound repair has been observed in individuals with congenital fibrinogen deficiency (Al-Mondhiry and Ehmann 1994). Third, fibrin(ogen) appears to be necessary for inflammatory responses in vivo (Colvin et al. 1973; McRitchie et al. 1991; Tang and Eaton 1993) and directs leukocyte transendothelial cell migration (Languino et al. 1995). Finally, fibrinogen fragments have been shown to have both chemotactic and immunosuppressive activities (Plow and Edgington 1986; Skogen et al. 1988). One hypothesis that emerges is that fibrin provides a critical provisional matrix at sites of infection or injury in which cells can proliferate, organize, and carry out specialized functions.

If correct, then fibrin(ogen) is likely to play a key role in the pathobiology of common diseases that promote or result from chronic tissue injury, including cancer, atherosclerosis, and sickle cell disease. Notably, fibrin(ogen) is a significant component of atherosclerotic lesions (Bini and Kudryk 1992) and interacts with many of the cells that appear to contribute to plaque development, including platelets, endothelial cells, macrophages, leukocytes, and smooth muscle cells (Sherman and Lee 1977; Wright et al. 1983; Dejana et al. 1985; Altieri et al. 1986; Bennett 1991; Naito et al. 1992; Majerus 1994). Nevertheless, the lack of a suitable in vivo system for manipulating fibrinogen levels and/or its functional properties has precluded definitive studies regarding a role of fibrin(ogen) in atherogenesis. Similarly, fibrin is a common component of tumor tissue and has been suggested to contribute significantly to tumor pathogenesis (Dvorak 1986; Nagy et al. 1995). However, the advantages and/or liabilities of local fibrin(ogen) deposition for tumor progression are still obscure.

To define precisely the role of fibrin(ogen) in development, hemostasis, wound repair, and the inflammatory response and to provide an in vivo model system for testing the proposed relationships between fibrin(ogen) and cancer biology, atherosclerosis, and other common diseases, the fibrinogen A $\alpha$-chain gene was disrupted in mice. We report that fibrinogen $A \alpha$-chain deficiency results in the elimination of all fibrinogen polypeptides from the circulation, the loss of both platelet aggregation and clotting function, and a high risk of spontaneous bleeding in both neonates and adults. Remarkably, these animals can resolve some hemorrhagic events and most survive well into adulthood.

\section{Results}

Disruption of the mouse fibrinogen A $\alpha$-chain gene

To eliminate production of the fibrinogen A $\alpha$-chain gene product in transgenic mice, a replacement-type targeting vector (Fig. 1A) was prepared from the cloned murine A $\alpha$-chain gene (Fig. 1B). The targeting vector was constructed by introduction of a $6-\mathrm{kb}$ minigene encoding human hypoxanthine phosphoribosyl transferase (HPRT) (Reid et al. 1990) into a unique Ball site within exon 1. The inserted HPRT cassette served to both disrupt the $A \alpha$-chain gene within the signal peptide sequence (14 amino acids downstream of the initiator methionine) and provide a means to positively select embryonic stem (ES) cells that had stably incorporated the transfected transgene. The A $\alpha$-chain targeting DNA was introduced by electroporation into the HPRT-deficient ES cells, E14TG2a (Hooper et al. 1987), and 11 of $\sim 220$ transfectants analyzed were found to have incorporated the targeting vector by homologous recombination based on Southern blot hybridization analysis of genomic DNA using the diagnostic enzymes PvulI, Ball, and PstI and PCR analysis (data not shown).

One of the 11 targeted ES cell clones (designated 37G) was injected into 3.5-day-old $\mathrm{C} 57 \mathrm{Bl} / 6 \mathrm{~J}$ blastocysts, resulting in the generation of four chimeric males. Three of these males sired offspring carrying a mutant $\mathrm{A} \alpha$ allele when mated to either CF-1 or C57Bl/6J females based on Southern blot (e.g., see Fig. 1C) and PCR assays (data not shown). All of the mice identified as heterozygous for the modified A $\alpha$-chain gene in this and all subsequent crosses were normal in appearance and phenotypically indistinguishable from wild-type littermates. Crosses of heterozygous mice resulted in the birth of mice homozygous for the disrupted fibrinogen A $\alpha$-chain gene $\left(A \alpha^{-1-}\right)$. Based on the Mendelian pattern of transgene inheritance, few, if any, fibrinogen A $\alpha$-chain-deficient mice are lost in utero: Of the first 309 progeny derived from $A \alpha^{+/-}$parents with a 129/CF-1 genetic background, $71(23 \%)$ were homozygous for the mutant $\mathrm{A} \alpha$-chain allele $\left(\mathrm{A}^{-1-}{ }^{-1}, 157(51 \%)\right.$ were heterozygous $\left(\mathrm{A} \alpha^{+1-}\right)$, and $81(26 \%)$ were homozygous for the wildtype $\mathrm{A} \alpha$-chain allele $\left(\mathrm{A} \alpha^{+1+}\right)$.

\section{Homozygous mutant mice do not express detectable fibrinogen $A \alpha$-chain mRNA or plasma fibrinogen}

Fibrinogen A $\alpha$-chain mRNA was not detectable in liver RNA isolated from $\mathrm{A \alpha}^{-1-}$ mice by Northern blot hybridization using a high specific activity radiolabeled $\mathrm{A} \alpha$ chain-specific probe (Fig. 2). In contrast, the A $\alpha$-chain mRNA was easily detected in control liver RNA isolated from $\mathrm{A \alpha}^{+1+}$ mice when analyzed in parallel. Interestingly, the levels of $B \beta$ - and $\gamma$-chain mRNA in the same RNA preparations were not significantly different, suggesting that the wholesale loss of one of the three fibrinogen transcripts does not alter either the transcription or the coordinate expression of the two remaining fibrinogen genes. Hepatic fibrinogen gene expression appears to be insensitive to the level of circulating fibrinogen (see 
Suh et al.

A

Aa Chain Gene Targeting Vector

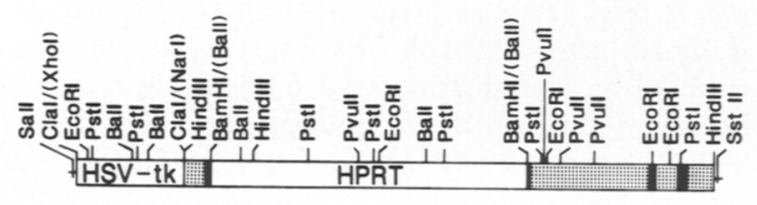

B

Normal AaChain Allele

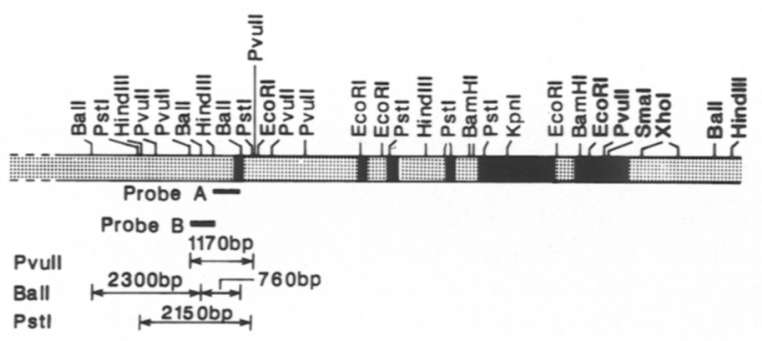

Targeted Aa Chain Allele

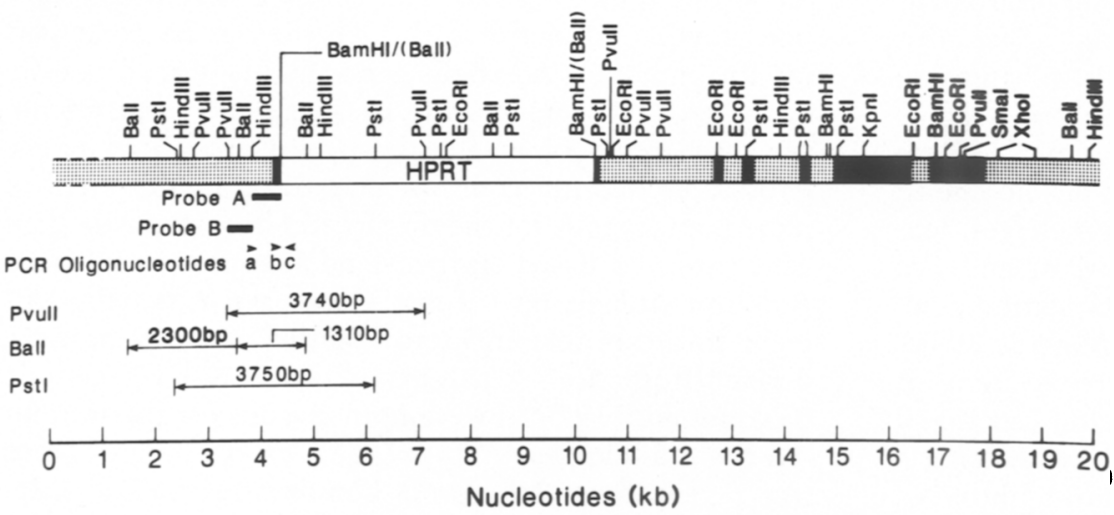

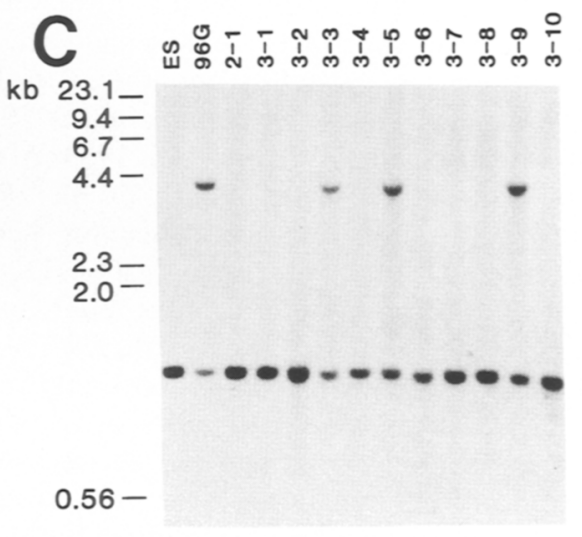

Figure 1. Targeting of the fibrinogen $\mathrm{A} \alpha$ chain gene by homologous recombination. (A) Structure of the A $\alpha$ chain targeting vector transfected into ES cells. Solid areas indicate exons, and stippled areas indicate introns and 5'-flanking sequences. The HPRT minigene (inserted into a Ball site in exon 1) and HSV-tk minigene (inserted into the 5 '-flanking region) are indicated by open areas. (B) Structure of the normal and targeted fibrinogen $\mathrm{A} \alpha$-chain alleles. Bars labeled Probe A and Probe B indicate regions complementary to hybridization probes used in genomic Southern blot analysis. Probe A is a 500-bp HindIII-BamHI fragment complementary to a region contained within the targeting vector and Probe $B$ is a PvuII-HindIII 430-bp fragment complementary to a region that was not included in the targeting vector. The positions and sizes (bp) of restriction fragments detected by either Probe A or Probe B are indicated. Arrowheads indicate the position of synthetic oligonucleotide primers $a, b$, and $c$ used in PCR assays to detect the targeted A $\alpha$-chain gene $(a$ and $c)$ and the targeting vector $(b$ and $c) .(C)$ Representative Southern blot analysis of PvuII-digested tail DNA prepared from the offspring of chimeric founder males and wild-type CF-1 females using hybridization Probe A. DNA samples from normal (ES) and A $\alpha$ chain-targeted (96G) ES cells were analyzed in parallel as controls. The sizes and relative positions of molecular mass marker fragments are indicated at left.

below) in the absence of acute challenges and fibrin(ogen) degradation products (see Crabtree and Kant 1982).

Whole blood and plasma isolated from $\mathrm{A} \alpha^{-1-}$ mice uniformly failed to clot either spontaneously or when combined with thrombin in vitro (Table 1). In contrast, whole blood and plasma collected from both $\mathrm{A}^{{ }^{+1-}}$ and $\mathrm{A \alpha}^{+1+}$ mice clotted in $\sim 15 \mathrm{sec}$ when combined with thrombin at $37^{\circ} \mathrm{C}$ (Table 1). Therefore, $\mathrm{A} \alpha^{-1-}$ mice entirely lack clotting function when tested in a simple, standard in vitro assay diagnostic of fibrinogen. Nevertheless, many other general hematological parameters were normal in fibrinogen-deficient mice. For example, no significant differences were found in whole blood samples collected from $\mathrm{A} \alpha^{+1+}, \mathrm{A \alpha}^{+1-}$, and $\mathrm{A} \alpha^{-1-}$ mice with regard to platelet, red cell, and white cell counts, hematocrit, and hemoglobin (Table 1). Despite the availability of platelets and presumably all other clotting factors, fibrinogen-deficient mice were not able to control the loss of blood when challenged with a relatively modest nailbed wound in the fifth digit of the hind leg (Table 1). $\mathrm{A}^{+/+}$and $\mathrm{A \alpha}^{+/-}$mice were able to control bleeding from the base of the nailbed in less than 4 min, whereas $\mathrm{A} \alpha^{-1-}$ mice continued to bleed for as long as they were observed (15-30 min).

Consistent with the clotting data and the hepatic $A \alpha-$ chain mRNA data, fibrinogen could not be detected in 

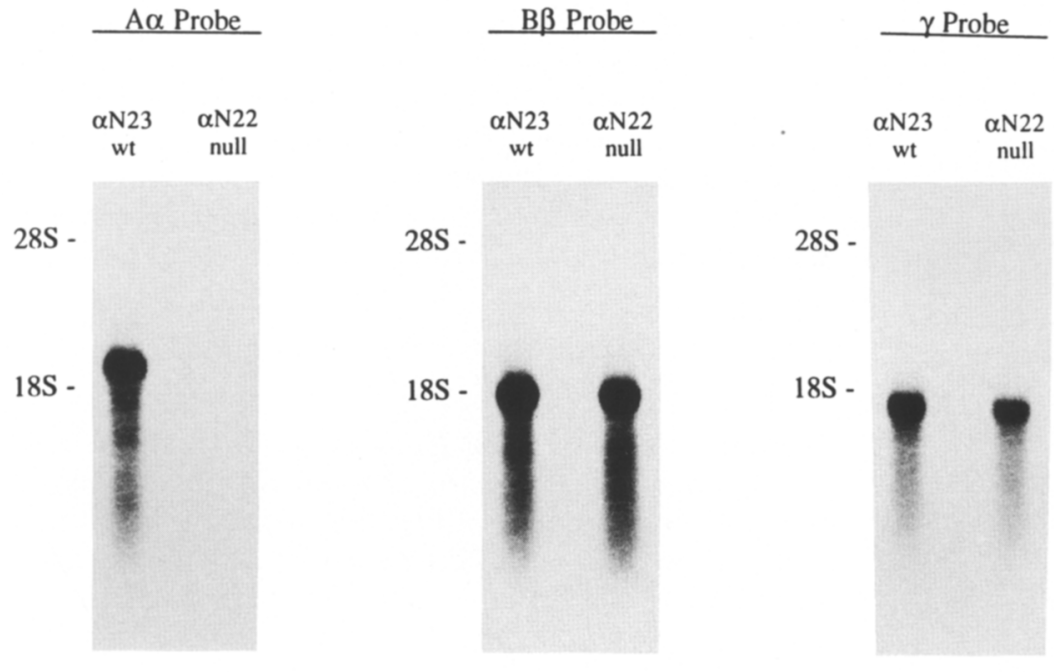

Figure 2. Analysis of fibrinogen $\mathrm{A} \alpha-, \mathrm{B} \beta-$ and $\gamma$-chain mRNAs in the livers of $\mathrm{A}^{+1+}$ and $\mathrm{A} \alpha^{-1-}$ mice. Total RNA preparations from the livers of 8-week-old $A \alpha^{+/+}(\alpha \mathrm{N} 23)$ and $A \alpha^{-1-}$ $(\alpha \mathrm{N} 22)$ littermates were fractionated by agarose gel electrophoresis ( $20 \mu \mathrm{g}$ per lane), transferred to nitrocellulose, and hybridized to ${ }^{32} \mathrm{P}$-labeled probes complementary to either the mouse A $\alpha$ (left), $\mathrm{B} \beta$ (middle), or $\gamma$ (right) fibrinogen mRNAs. The slightly diminished $\gamma$-chain mRNA in $\alpha \mathrm{N} 22$ relative to $\alpha \mathrm{N} 23$ was attributed to RNA loading differences based on later analysis with a plasminogen cDNA probe (data not shown).

plasma samples of $A \alpha^{-1-}$ mice using a sensitive and quantitative capture ELISA assay (Fig. 3A). Furthermore, none of the three component chains of fibrinogen were detectable in whole blood samples of homozygous $A \alpha$ chain-targeted mice when analyzed by Western blot analysis using a polyclonal antibody reactive with all three mouse fibrinogen polypeptide chains (Fig. 3B). Based on immunoblot analysis of blood samples serially diluted over a six-log range, any fibrinogen-related material in the circulation of $\mathrm{A}^{-/-}$mice is present at levels at least four orders of magnitude below the fibrinogen level in $\mathrm{A \alpha}^{+/+}$mice (data not shown). The elimination of the A $\alpha$-chain gene product resulted in the secondary elimination from the circulation of the fibrinogen $B \beta$ and $\gamma$ polypeptide chains; there is no evidence of either individual fibrinogen chains or a novel secreted form of fibrinogen made up of only the $B \beta$ and $\gamma$ chains in either plasma or whole blood of A $\alpha$ chain-deficient mice. The absence of the $B \beta$ and $\gamma$ chains in the circulation of $A \alpha$ chain-deficient mice was not the result of the loss of hepatic $\mathrm{B} \beta$ and $\gamma$-chain polypeptide synthesis. Consistent with the normal levels of hepatic $B \beta$ and $\gamma$-chain
mRNA in A $\alpha$ chain-deficient mice, fibrinogen-related antigen was easily detected within hepatocytes (but not in the sinusoidal space) of liver sections processed for immunohistochemistry (data not shown). These data suggest that the $B \beta$ and $\gamma$ chains are synthesized by $\mathrm{A} \alpha^{-1-}$ hepatocytes in vivo, but they cannot be secreted in the absence of the A $\alpha$ chain and full assembly of fibrinogen. This observation is consistent with the finding that cultured cells transfected with expression vectors encoding just one or two of the three fibrinogen chains fail to secrete fibrinogen polypeptides, whereas cotransfection of expression vectors encoding all three chains results in secretion of fully assembled fibrinogen (Roy et al. 1991; Huang et al. 1993).

Fibrinogen constitutes $\sim 1 \%$ of total hepatic protein synthesis, and fibrinogen deposits within hepatocytes have been documented in some human patients with severe hypofibrinogenemia (Wehinger et al. 1983). Therefore, the livers from three $\mathrm{A} \alpha^{-1-}$ mice ranging in age from 1 day to 8 weeks were examined by electron microscopy to determine whether the inability to secrete the $\mathrm{B} \beta$ and $\gamma$ chains by $A \alpha^{-1-}$ hepatocytes resulted in

Table 1. Hematological analysis of fibrinogen-deficient transgenic mice

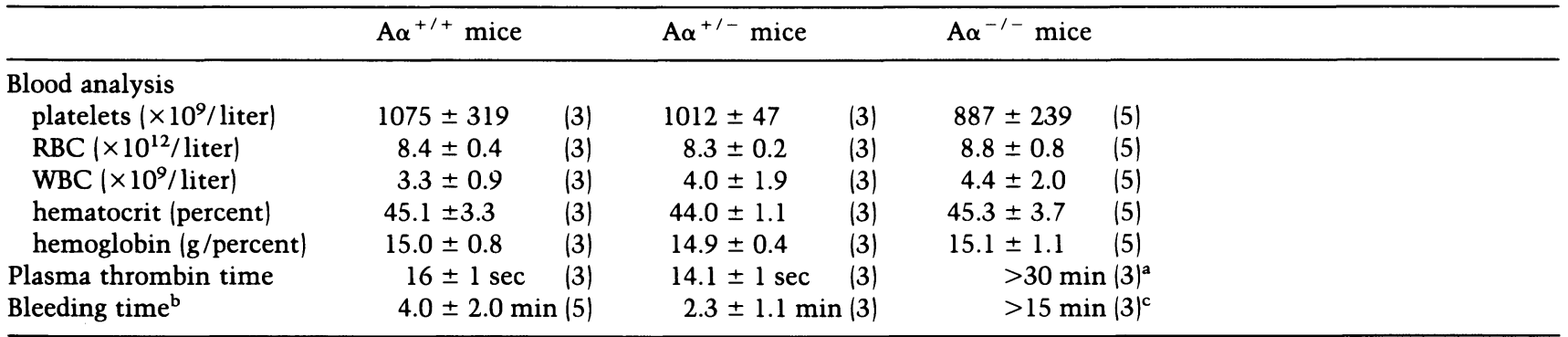

Data presented are the mean \pm S.D. with the number of mice analyzed in parentheses. All mice analyzed were $\sim 6.5$ months of age.

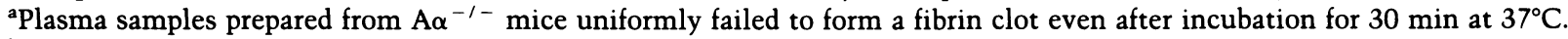

bBleeding times following a standard nail-bed injury were established as described in Materials and methods.

${ }^{\mathrm{c}}$ The bleeding time test was terminated in two mice after $15 \mathrm{~min}$ of persistent bleeding. The test was terminated in one additional mouse after $30 \mathrm{~min}$ of persistent bleeding. 


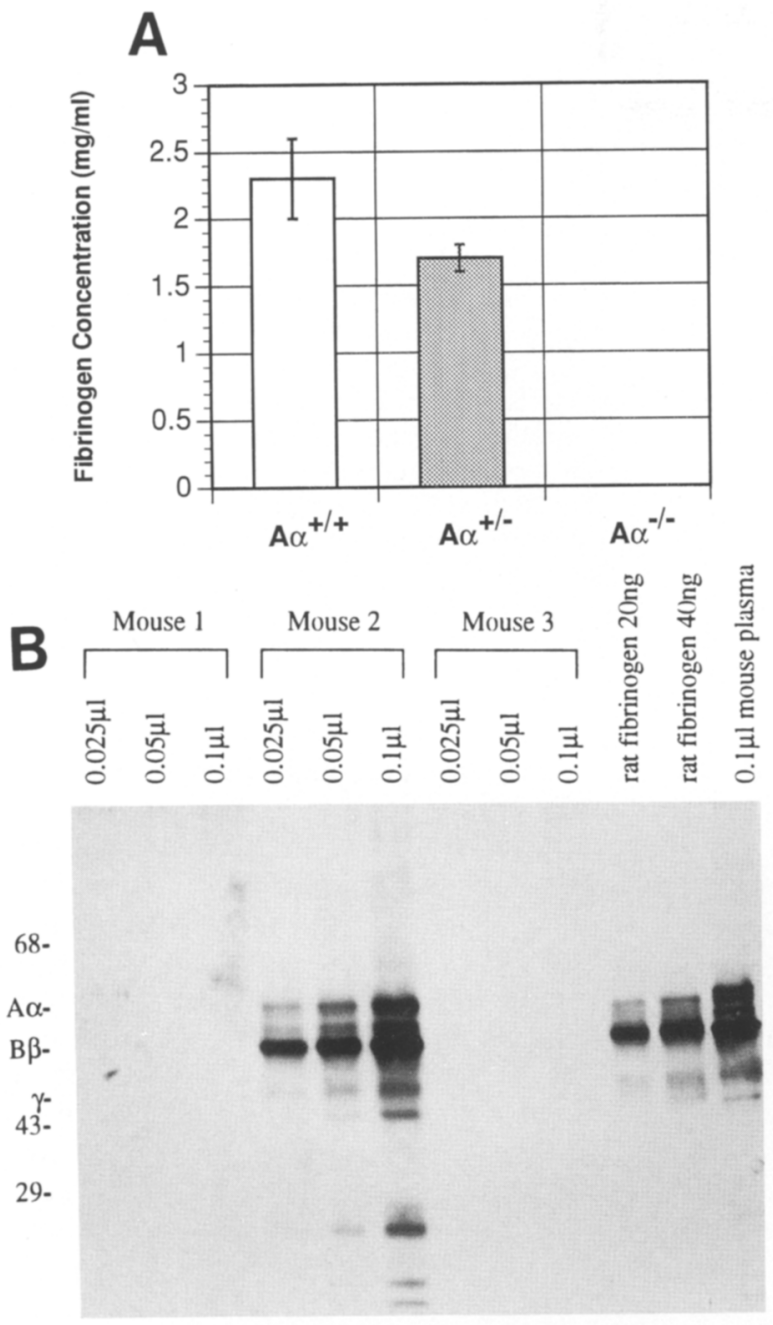

Figure 3. ELISA and Western blot immunoassay of fibrinogen in the blood of control and $\mathrm{A} \alpha^{-1-}$ mice. (A) ELISA assay of plasma fibrinogen levels in $\mathrm{A} \alpha^{+/+}, \mathrm{A} \alpha^{+/-}$, and $\mathrm{A} \alpha^{-/-}$mice. Results plotted for $\mathrm{A \alpha}^{+/+}$and $\mathrm{A} \alpha^{+/-}$mice are the mean \pm S.D. using four independent plasma samples. No fibrinogen was detected using plasma samples from two $\mathrm{A} \alpha^{-1-}$ mice. (Note that the less than twofold reduction of plasma fibrinogen in $\mathrm{A} \alpha^{+1-}$ mice relative to $\mathrm{A} \alpha^{+/+}$mice would be expected if $\mathrm{A} \alpha$-chain synthesis is not rate limiting for fibrinogen assembly and secretion in wild-type mice.) $(B)$ Western immunoassay of whole blood samples collected from a 6-day-old $\mathrm{A} \alpha^{-1-}$ neonate (Mouse 1), a 2-day-old $\mathrm{A} \alpha^{+/-}$neonate (Mouse 2), and a 2-dayold $\mathrm{A} \alpha^{-1-}$ neonate (Mouse 3). Samples containing $0.025 \mu \mathrm{l}$, $0.05 \mu \mathrm{l}$, and $0.1 \mu \mathrm{l}$ of whole blood were analyzed simultaneously for each mouse tested. Purified rat fibrinogen and normal adult mouse plasma were analyzed in parallel as controls. Fibrinogen was detected using a rabbit antiserum raised against rat fibrinogen and a chemiluminescence detection system and autoradiography. For the data shown, the film was exposed to the blot for $\sim 5 \mathrm{sec}$. No fibrinogen was detected in the blood of either Mouse 1 or Mouse 3 even with exposure times that greatly overexposed the Mouse 2 and control lanes.

either alteration or disruption of the endoplasmic reticulum or intracellular fibrinogen deposits. Hepatocyte morphology was indistinguishable between $\mathrm{A}^{-1-}$ and control mice, and no evidence was found for cellular deposits or alteration of the endoplasmic reticulum and Golgi architecture in $\mathrm{A}^{-/-}$mice (data not shown). The turnover rate of intracellular $B \beta$ and $\gamma$ chains in $A \alpha^{-1-}$ mice is apparently sufficient to avoid a deleterious accumulation of individual and partially assembled chains in hepatocytes in the absence of other challenging factors.

\section{Spontaneous bleeding events in fibrinogen-deficient neonates}

Fibrinogen-deficient mice appeared normal at birth, but $\sim 30 \%$ developed overt intra-abdominal, subcutaneous, joint and/or periumbilical bleeding within 2 days after birth (e.g., see Fig. 4A,B). Nineteen of $71 \mathrm{~A} \alpha^{-1-}$ neonatal offspring derived from crosses between hemizygous mice developed one or more bleeding events, whereas none of

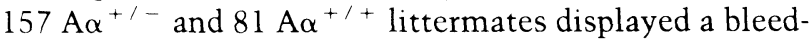
ing phenotype. Remarkably, these spontaneous and often severe bleeding events in fibrinogen-deficient neonates proved fatal in only a fraction of mice; about twothirds of neonates that sustained an overt bleed ultimately controlled the loss of blood and survived the neonatal period. Thus, $\sim 90 \%$ of all fibrinogen-null mice survived the neonatal period despite their risk of bleeding (see following section for additional survival data). Interestingly, those mice that developed an overt bleed were generally active, nursed, and did not display other signs of illness. Milk engorgement might initiate bleeding in at least some of these mutant neonates. Microvascular trauma sustained during passage of the newborns through the birth canal seems likely to contribute significantly to the onset of both head and neck subcutaneous bleeding.

Microscopic examination of fixed tissues of fibrinogen-deficient neonates revealed that spontaneous bleeding occurred in a variety of tissues. However, the occurrence, tissue distribution, and severity of these bleeding events were quite variable between individuals and appeared to be a result of chance vascular breaks. Figure 4 shows two representative examples of the histopathology observed in fibrinogen-deficient newborns. Consistent with the overt appearance of hemorrhaging in the head, trunk, and soft tissue around joints, subcutaneous bleeding (extravascular pools of red cells) was detected in histological analysis of these tissues (Fig. 4C; data not shown). Evidence of bleeding into the nasopharynx was also found in several individuals (Fig. 4D).

\section{Survival of fibrinogen-deficient mice is dependent on genetic background}

Although $>90 \%$ of $\mathrm{A}^{-1-}$ mice in a 129/CF-1 hybrid genetic background survived to weaning age ( $\sim 21$ days), only half of these mice survived beyond 70 days of age (Fig. 5). The apparent cause of death in the majority of these juvenile and young adult $\mathrm{A} \alpha^{-/-}(129 / \mathrm{CF}-1)$ mice was a massive intra-abdominal hemorrhage (see section below for further details). The survival curve generated using the combined data for both male and female 


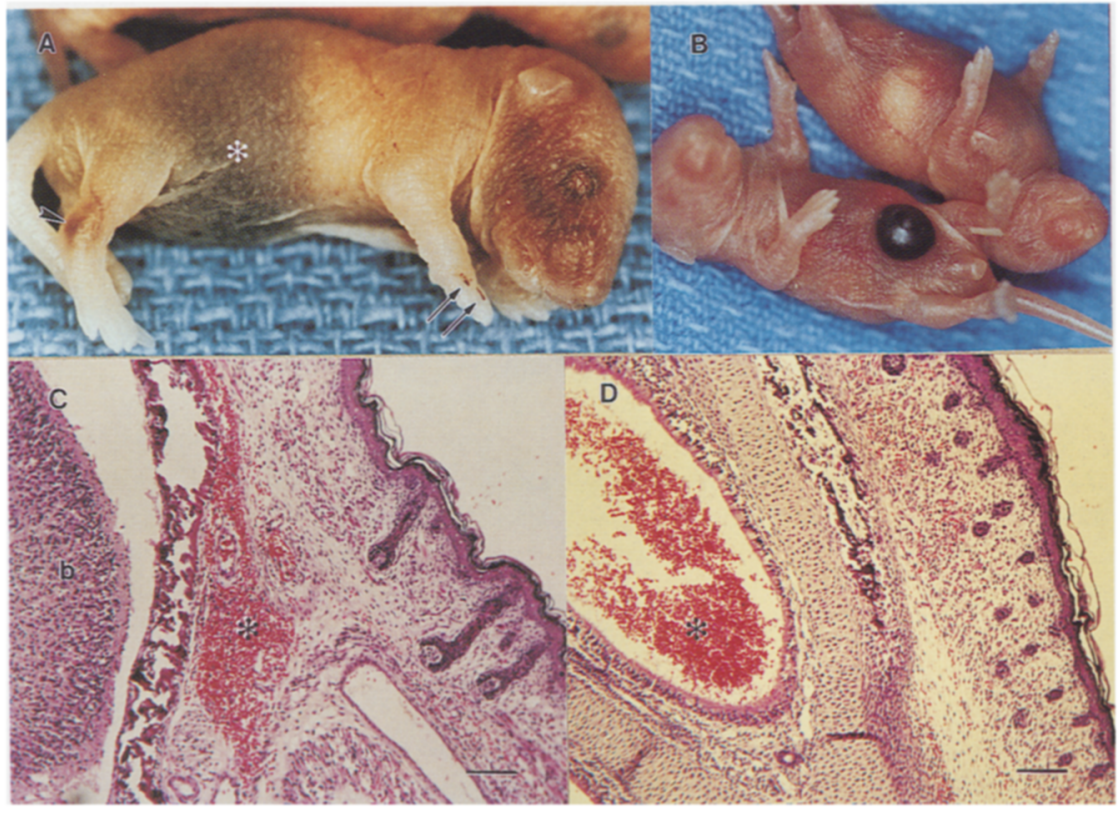

Figure 4. Spontaneous bleeding events in $\mathrm{A \alpha}^{-1-}$ neonates. $(A)$ One-day-old $\mathrm{A \alpha}^{-1-}$ mouse displaying severe bleeding in the abdominal cavity $\left({ }^{*}\right)$, subcutaneous hemorrhage in the face, head, and neck, bleeding around the joint in right hind leg (arrowhead), and scattered petechiae (arrow). (B) Periumbilical hematoma in 1-day-old $\mathrm{A}^{-1-}$ mouse. (C) Section through the head of a newborn $\mathrm{A \alpha}^{-1-}$ mouse showing the site of a subcutaneous bleeding event between the epidermis and skull $\left({ }^{*}\right)$. (b) Brain. Bar, $100 \mu \mathrm{m} .(D)$ Section through the snout of a newborn $A \alpha^{-1-}$ mouse showing minor bleeding in the nasopharynx $\left({ }^{*}\right)$. Bar, $100 \mu \mathrm{m}$.
$\mathrm{A \alpha}^{-1-}$ mice (shown in Fig. 5) was similar to the curves generated when the data on males and females were plotted separately; females displayed a small $(<10 \%)$ advantage over males in survival profile in the $129 /$ CF-1 genetic background (data not shown). This is particularly remarkable because one might expect breeding-age females to be at high risk for fatal abdominal hemorrhaging with each ovulation event (approximately six ovarian follicles would be expected to rupture about every 4 to 5 days in breeding-age females $>50$ days old). Apparently, any bleeding associated with follicular rupture is not life threatening in $\mathrm{A \alpha}^{-1-}$ mice. A second notable feature regarding the survival characteristics of $A \alpha^{-1-}$ (129/CF1) mice is that animals of both sexes have a particularly

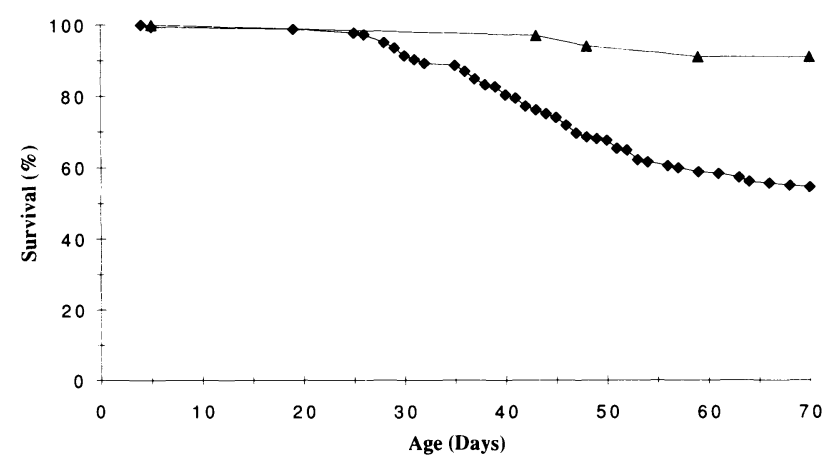

Figure 5. Survival characteristics of $\mathrm{A \alpha}^{-1-}$ mice on two genetic backgrounds. Kaplan-Meier plots showing survival profiles of $\mathrm{A \alpha}^{-1-}$ mice on 129/CF-1 ( $)$ and C57Bl/6J ( $\mathbf{\Delta}$ ) genetic backgrounds. The plots shown reflect the survival data on 185 $\mathrm{A \alpha}^{-1-}(129 / \mathrm{CF}-1)$ and $34 \mathrm{A \alpha}^{-1-}(\mathrm{C} 57 \mathrm{Bl} / 6 \mathrm{~J})$ mice that lived to least 5 days of age and could be followed for a minimum of 10 weeks in the same room with the same caregivers. high risk of developing fatal bleeding in the period between 30 and 60 days of age (Fig. 5). Interestingly, despite considerable losses during this time frame, those mice surviving beyond 90 days of age are likely to survive much longer. Of 42 fibrinogen-deficient mice that survived 3 months and could be followed over an additional 9-month period, $34(81 \%)$ survived beyond 6 months, 28 $(67 \%)$ survived beyond 9 months of age, and $24(57 \%)$ survived to 1 year of age. The potential for long-term survival in $\mathrm{A \alpha}^{-1-}$ mice is also illustrated by the fact that the oldest $A \alpha^{-1-}(129 / \mathrm{CF}-1)$ mice in our colony have survived beyond 24 months of age. Like the younger fibrinogen-deficient animals, the cause of death in older $\mathrm{A}^{-1-}$ mice is generally intra-abdominal hemorrhage.

To examine the possible influence of genetic background on the frequency of fatal spontaneous bleeding events in fibrinogen-deficient mice, a founder mouse and each subsequent generation of $\mathrm{A}^{+/-}$mice were crossed to $\mathrm{C} 57 \mathrm{Bl} / 6 \mathrm{~J}$ mice. Following the sixth generation backcross to $\mathrm{C} 57 \mathrm{Bl} / 6 \mathrm{~J}, \mathrm{A \alpha}^{+/-}$were interbred to raise $\mathrm{A} \alpha^{-1-}$ mice (note that six backcrosses to $\mathrm{C} 57 \mathrm{Bl} / 6 \mathrm{~J}$ would yield a genetic background close to $\mathrm{C} 57 \mathrm{Bl} / 6$ but not formally congenic). Unlike the $\mathrm{A}^{-1-}$ mice in the mixed 129/ CF-1 background, the $\mathrm{A} \alpha^{-1-}(\mathrm{C} 57 \mathrm{Bl} / 6 \mathrm{~J})$ mice showed excellent survival characteristics not only as neonates but also as juveniles and adults (Fig. 5). Essentially all $\mathrm{A}^{-1-}(\mathrm{C} 57 \mathrm{Bl} / 6 \mathrm{~J})$ mice surviving the initial neonatal period survived to breeding age ( $\sim 50$ days), $91 \%$ (31 of 34 ) survived to 70 days, and $85 \%$ survived $>100$ days (Fig. 5; data not shown). It is important to note that the differences in survival characteristics observed between young $\mathrm{A \alpha}^{-1-}(\mathrm{C} 57 \mathrm{Bl} / 6 \mathrm{~J})$ and $\mathrm{A} \alpha^{-1-}(129 / \mathrm{CF}-1)$ mice were found with mouse colonies housed in the same room, with the same caregivers, and over the same time 
period. The factors that contribute to the superior survival characteristics of the $\mathrm{A} \alpha^{-1-}(\mathrm{C} 57 \mathrm{Bl} / 6 \mathrm{~J})$ mice relative to the $\mathrm{A} \alpha^{-1-}(129 / \mathrm{CF}-1)$ mice have not yet been established. However, it has been shown that blood collected from $A \alpha^{-1-}$ mice with either genetic background contains no immunologically detectable fibrinogen, fails to clot, and does not support ADP-induced platelet aggregation (see below).

\section{Spontaneous hemorrhage in iuvenile and adult fibrinogen-deficient mice}

A key question raised in these studies is the sources of the free blood in the $\mathrm{A} \alpha^{-1-}(129 / \mathrm{CF}-1)$ mice that developed fatal intra-abdominal hemorrhage, particularly in the high-risk time frame between 30 and 60 days of age. It is notable in this regard that the majority of $1-$ to 2-month-old $\mathrm{A} \alpha^{-1-}$ mice that developed intra-abdominal bleeds also had prominent hepatic subcapsular hematomas (Fig. 6A,B), often at the interface of liver leaflets or beneath the sternum. These lesions occurred in $\mathrm{A} \alpha^{-1-}$ mice from both the 129/CF-1 and C57Bl/6J genetic backgrounds, were often $>1 \mathrm{~mm}$ in diameter, and varied in number in individual $\mathrm{A} \alpha^{-1-}$ mice from none to over a dozen. No such lesions were ever observed in either $\mathrm{A}^{+/-}$or $\mathrm{A}^{+/+}$mice. Thus, the formation and subsequent rupture of these hepatic lesions, coupled with an inability to control blood loss, could account for observed fatal abdominal bleeding events in $\mathrm{A}^{-1-}$ mice. Evidence of hematoma rupture was occasionally found in gross examination of livers. Microscopic analysis of fixed liver tissues indicated that these lesions tended to be subcapsular (Fig. 6B-E), suggesting that they were the result of chance mechanical trauma rather than infection or other causes. No histological evidence of bacterial infection was observed, and these lesions were detected in mice shown to be serologically negative for mouse hepatitis virus and a broad panel of other common mouse pathogens, including Sendai virus, Reo3, GDVII, and mycoplasma. The hepatic lesions generally consisted of subcapsular blood pools, often with adjacent, patchy hepatic necrosis (Fig. 6B-D). Inflammation was not a prominent feature, although individual lesions did show lymphocyte or, very rarely, neutrophil accumulation in the vicinity. Some lesions appeared to have no confining structure, whereas others were surrounded by a highly organized fibrotic capsule, implying that the formation of these hematomas initiates an unusual wound healing response in which the migrating and proliferating cells, primarily fibroblasts, form a thick layer

Figure 6. Subcapsular hematomas in the liver and kidney of $\mathrm{A} \alpha^{-1}$ mice. $(A)$ Gross appearance of livers collected from two 9-week-old $\mathrm{A}^{-1-}$ littermates. Only one of these fibrinogen-deficient siblings displayed an overt subcapsular hematoma (left $t$. (B) Subcapsular fibroblasts organized around hematoma of a 4-week-old (*). Local areas of necrosis adjacent to the lesion are indicated with arrows. Bar, $350 \mu \mathrm{m} .(C)$ Higher magnification of $B$ showing thick layer of fibroblasts organized around blood pool $(*)$ and adjacent necrosis (arrows). Note that despite the substantial progress of cells in organizing around the blood pool there appears to be little or no infiltration of responding cells into the blood pool. Bar, $100 \mu \mathrm{m}$. (D) Highly organized subcapsular hematoma, probably representing the later stages of lesion resolution. Note local patches of hemosiderin-laden macrophages (arrowhead). Also note that the residual blood pool $(*)$ remains essentially free of infiltrating cells even after extensive local organization. Bar, $100 \mu \mathrm{m}$. (E) Foreign body-type giant cells (arrow) and dystrophic calcification (arrowhead) in an involuting hepatic lesion. Bar, $35 \mu \mathrm{m}$. $\{F \mid$ Organizing subcapsular fibroblasts ( ${ }^{*}$ ) surrounding a subcapsular renal hematoma in a 12week-old $\mathrm{A} \alpha^{-1-}$ mouse. Note the lack of infiltration of the responding cells into the blood pool. Bar, $100 \mu \mathrm{m}$.

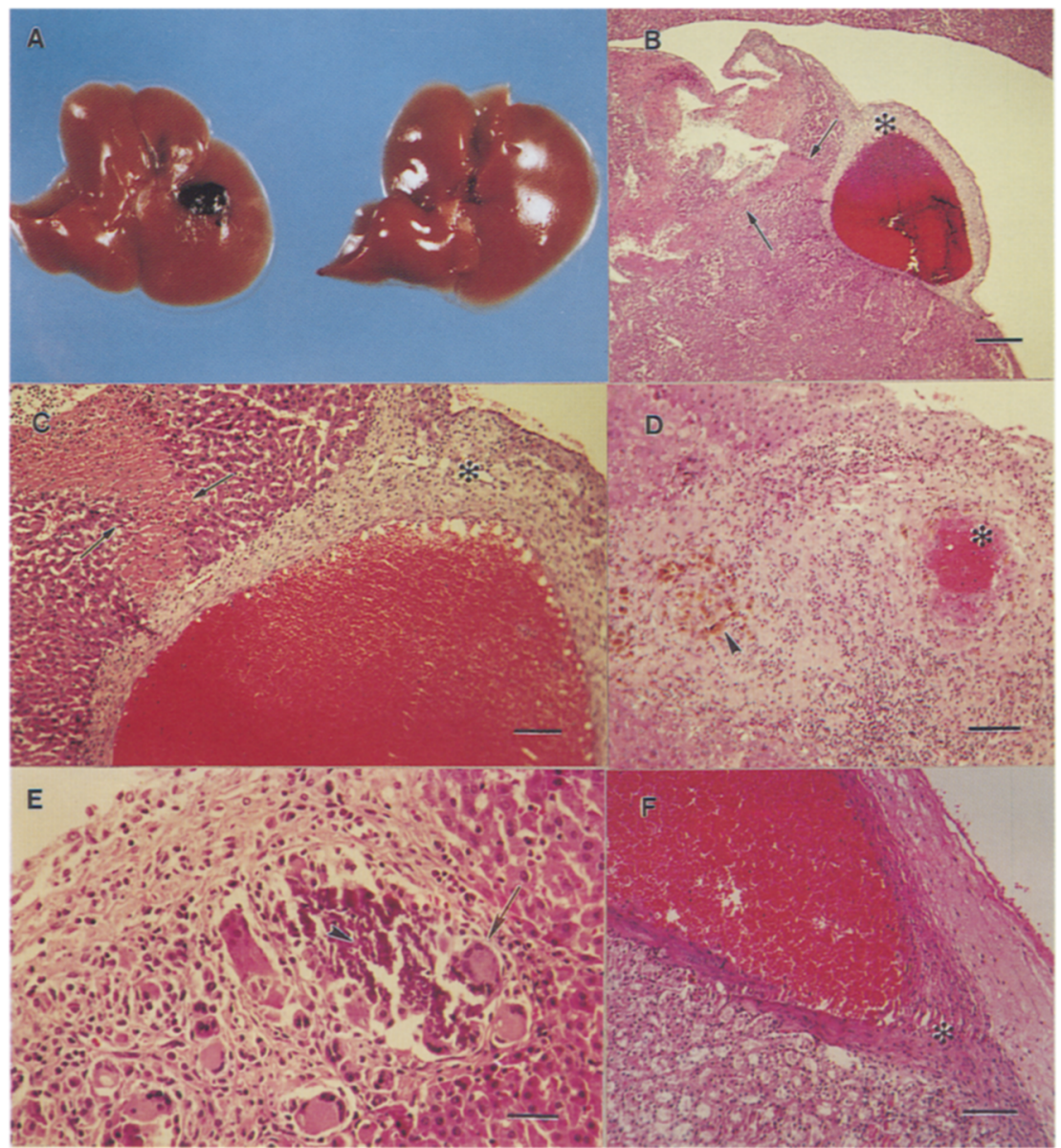


encapsulating but not infiltrating the hematomas (Fig. $6 \mathrm{~B}-\mathrm{D})$. The most intriguing aspect of these lesions is that despite the obvious organization "around" hematomas, generally little progress was evident in the penetration of organizing cells "into" hematomas. These data are consistent with the view that fibrin provides a critical initial matrix for the movement of cells into sites of injury. Many of these hematomas appeared to resolve by ingrowth of the encapsulating cells rather than by the standard pattern of macrophages and fibroblast infiltration (Fig. 6D). Such involuting lesions showed features of a granulomatous response with histiocytic foreign bodytype giant cells, hemosiderin-laden macrophages (Fig. 6D), and dystrophic calcification (Fig. 6E). The lesions were ultimately obliterated by formation of a fibrotic scar. The failure of cells to organize into blood-filled wound fields in $\mathrm{A \alpha}^{-1-}$ mice is apparently a consequence of the absence of fibrin(ogen) rather than some unusual feature of wound healing in the liver because a similar pattern was observed in spontaneous subcapsular hematomas in the kidney (e.g., see Fig. 6F).

Although the abdomen was the predominant site of bleeding among 190 juvenile and adult $\mathrm{A} \alpha^{-1-}$ (129/CF1) mice autopsied (see above), other sites of hemorrhage were also observed, including eight soft tissue $(4.2 \%)$, seven intraintestinal $(3.7 \%)$, six intrathoracic $(3.2 \%)$, and five subcapsular renal $(2.6 \%)$ bleeds. In addition, one 5 -week-old mouse sustained a subdural hematoma that resulted in compression of the left cerebral hemisphere (data not shown). No obvious bleeding events were detected in $\sim 5 \%$ of $\mathrm{A} \alpha^{-1-}$ mice autopsied.

\section{Spontaneous bleeding events in pregnant fibrinogen-deficient mice}

Breeding pairs consisting of $\mathrm{A} \alpha^{+/-}$females and either $\mathrm{A} \alpha^{+^{\prime}}$ - or $\mathrm{A} \alpha^{-1-}$ males produced normal size litters with the expected number of fibrinogen $\mathrm{A \alpha}^{-1-}$ offspring (see above). In contrast, no litters could be generated from $\mathrm{A}^{-1-}$ females regardless of the genotype of their male partners and the genetic background (i.e., 129/CF1, $\mathrm{C} 57 \mathrm{Bl} / 6 \mathrm{~J})$ of the breeding pair. Overt vaginal bleeding uniformly developed around day 10 of gestation in 16 crosses between $\mathrm{A} \alpha^{-1-}$ females and $\mathrm{A} \alpha^{-1-}$ males, 4 crosses between $\mathrm{A} \alpha^{-1-}$ females and $\mathrm{A} \alpha^{+/-}$males, and 6 crosses between $\mathrm{A} \alpha^{-1-}$ females and $\mathrm{A} \alpha^{+1+}$ males. These hemorrhagic events were fatal in eight of these animals, with death occurring within 2 days after the appearance of the overt bleeding. The remaining $18 \mathrm{fe}$ males were sacrificed as soon as the vaginal bleeding was observed, for microscopic analysis of the uterine tissues and associated developing embryos. Evidence of hemorrhage was seen within the uterine horns of each of these pregnant females upon gross inspection, especially around the embryos. Microscopic analysis of all of these mice revealed that substantial bleeding had occurred in the uterine cavity; however, there was no evidence of bleeding within any developing embryos or their amniotic or yolk sacs as long as the placentas were intact (Fig. 7A,B). Even when embryos had undergone advanced ne-

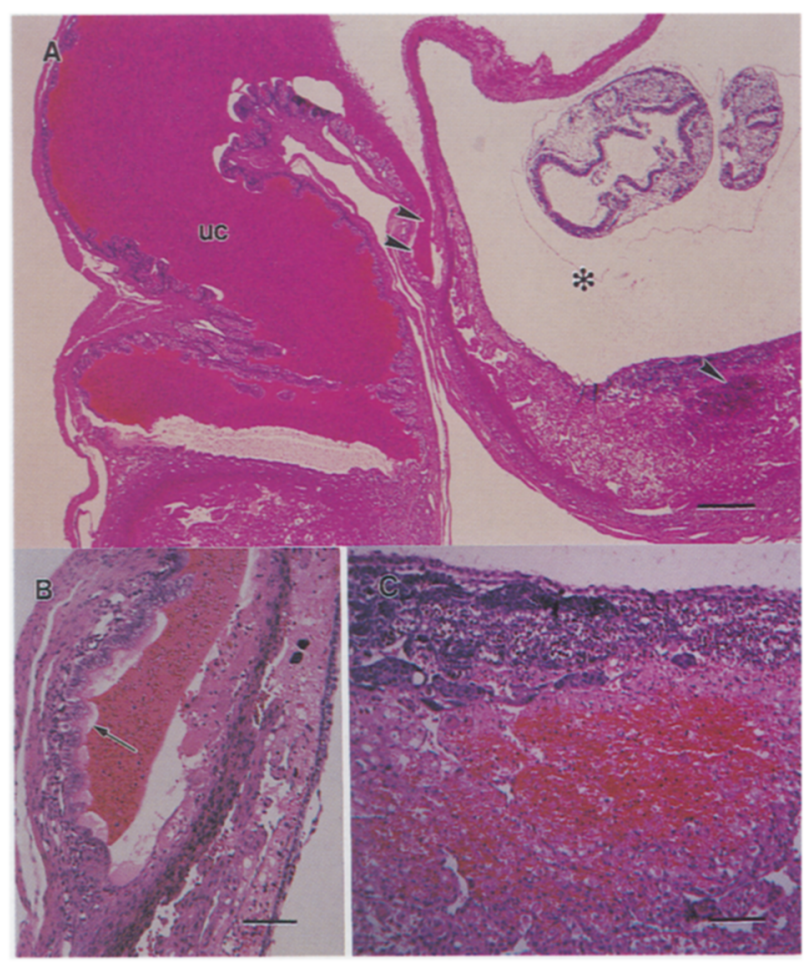

Figure 7. Maternal bleeding during early pregnancy in $\mathrm{A}^{-1-}$ mice. (A) Uterine tissue section from a 10-week-old $\mathrm{A} \alpha^{-1-}$ mouse eleven days after mating. The animal developed slow vaginal bleeding $\sim 36 \mathrm{hr}$ prior to sacrifice. The uterine cavity (uc) is filled with blood, whereas no blood was detected in either the neighboring necrotic embryo (top right) or the amniotic and exocoelomic cavities (*). Bar, $350 \mu \mathrm{m}$. (B) Higher magnification of region indicated with double arrowheads in $A$ showing the blood pool is in direct contact with the endometrial lining (arrow). Bar, $100 \mu \mathrm{m} .(C)$ Higher magnification of the placental region indicated with a single arrowhead in $A$. Bleeding is apparent in the labyrinthine layer of the placenta immediately below the ectoplacental plate. Bar, $100 \mu \mathrm{m}$. No free blood was apparent in any portion of the uterine or placental tissues of control mice mated and sacrificed in parallel with $\mathrm{A} \alpha^{-1-}$ mice (data not shown).

crosis, bleeding was apparent only in the uterine cavity (Fig. 7A). Evidence of bleeding was occasionally seen in the labyrinthine layer of placentas (Fig. 7C). The general location and volume of blood, the lack of nucleated (embryonic) red blood cells within the areas of hemorrhage, and the fact that $\mathrm{A} \alpha^{-/-}$females crossed to $\mathrm{A} \alpha^{+/+}$ males /carrying offspring that uniformly have one wildtype fibrinogen allele) develop intrauterine bleeding strongly suggests that hemorrhaging in these pregnant $\mathrm{A} \alpha^{-1-}$ mice was from a maternal source (Fig. 7). The development of the embryos in the fibrinogen $\mathrm{A \alpha}^{-1-}$ mothers was found to be arrested at approximately day 9 to day 10 of development based on the level of heart development and presence of the three primitive brain vesicles (Fig. 7; data not shown). Notably, at this time of gestation, embryonic trophoblasts are invading and disrupting maternal vasculature within the labyrinthine 
layer of the placenta (Cross et al. 1994). No failures to carry litters to term or microscopic evidence of uterine bleeding were ever observed in pregnant $\mathrm{A} \alpha^{+/-}$or $\mathrm{A}^{+1+}$ mice observed and sacrificed in parallel with $\mathrm{A} \alpha^{-1-}$ mice (data not shown).

\section{Platelet aggregation in fibrinogen-deficient mice}

Fibrinogen-deficient mice provide a means to rigorously define the role of fibrinogen in both platelet adhesion and aggregation by allowing the analysis of platelets suspended in autologous plasma (or whole blood) that lacks fibrinogen but is otherwise complete. Platelet suspensions prepared from $\mathrm{A \alpha}^{-1-}$ mice failed to aggregate in a standard aggregometer assay when combined with $10 \mu \mathrm{M}$ ADP (Fig. 8A). However, ADP did stimulate platelet shape change as judged by the small decrease in transmitted light through platelet suspensions (Fig. 8A). In contrast, platelet suspensions prepared from $\mathrm{A} \alpha^{+/+}$(Fig. $8 \mathrm{~A}$ ) or $\mathrm{A}^{+/-}$(data not shown) mice promptly formed large aggregates after addition of ADP in parallel assays. The failure of platelets derived from $\mathrm{A} \alpha^{-1-}$ mice to aggregate was directly related to the absence of a plasma constituent rather than an inherent functional deficit in the platelets themselves. $\mathrm{A \alpha}^{-1-}$ platelets promptly formed large aggregates following ADP addition when the platelet suspensions were combined with an equal volume of plasma prepared from $\mathrm{A}^{+/-}$or $\mathrm{A}^{+/+}$mice (data not shown). The component in normal plasma that supports $\mathrm{A} \alpha^{-1-}$ platelet aggregation appears to be fibrinogen. $\mathrm{A} \alpha^{-1-}$ platelets aggregated normally following ADP addition when purified fibrinogen was added to platelet suspensions in autologous plasma (Fig. 8B). Fur-
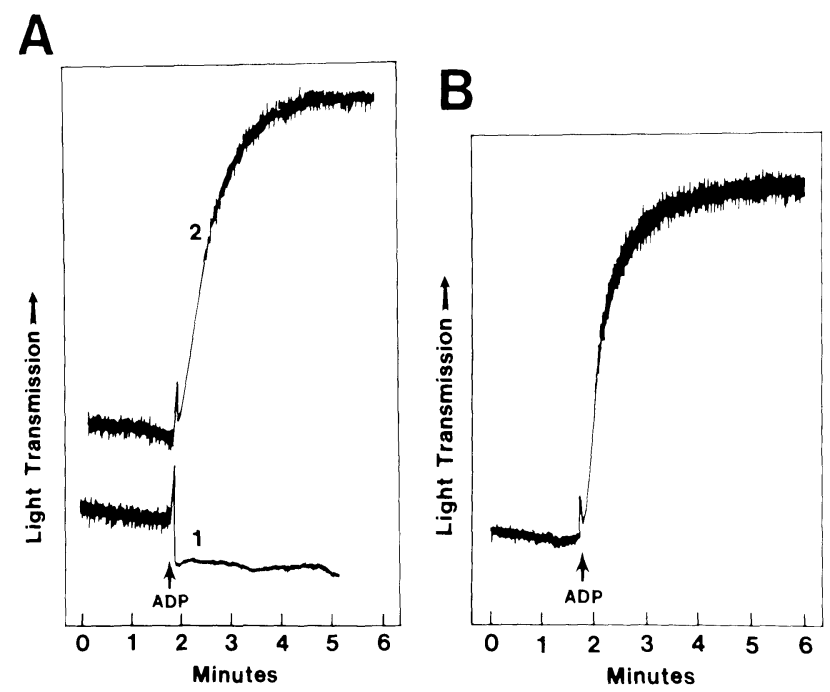

Figure 8. Aggregation of platelets derived from $A \alpha^{-1-}$ mice is dependent on exogenously added fibrinogen. $(A)$ ADP-stimulated platelet aggregation using platelets collected from $\mathrm{A}^{+1+}$ (tracing 2) and $\mathrm{A} \alpha^{-1-}$ (tracing 1) mice suspended in autologous plasma. (B) ADP-stimulated platelet aggregation using platelets prepared from $A \alpha^{-1-}$ mice suspended in autologous plasma supplemented with $500 \mu \mathrm{g} / \mathrm{ml}$ of purified rat fibrinogen. thermore, the aggregation of $\mathrm{A} \alpha^{-1-}$ platelets was not strictly dependent on the order of ADP and fibrinogen addition. ADP-stimulated $\mathrm{A}^{-1-}$ platelets that had undergone shape change but failed to aggregate were found to promptly form large aggregates with the later addition of purified fibrinogen; only a small decrease in the degree of platelet aggregation was apparent when fibrinogen was added within $5 \mathrm{~min}$ of ADP addition (data not shown). The degree of platelet aggregation achieved with $\mathrm{A} \alpha^{-1-}$ platelets was found to be dependent on the concentration of the supplied fibrinogen, and substantial platelet aggregation was observed at fibrinogen concentrations of $<1 \%$ that of the normal plasma (data not shown). Platelet aggregation in $\mathrm{A}^{-1-}$ platelet-rich plasma was also found to be dependent on exogenous fibrinogen with two other platelet-activating agents, collagen and thrombin (data not shown).

\section{Discussion}

These studies show that mice can establish a normal hemovascular system and complete embryonic development despite a total lack of fibrinogen and clotting function. However, life without fibrinogen is precarious; spontaneous and often fatal bleeding events, particularly intra-abdominal hemorrhage, are common in both neonates and adults. One of the most remarkable findings is that severe internal bleeding events are not necessarily fatal. The majority of newborns with obvious free blood in their peritoneal cavity (such as the mouse shown in Fig. 4A) ultimately manage to control blood loss, clear their abdomens, and survive the neonatal period. Maternal fibrinogen passing through the placenta is a potential source of protection for the fetal and newborn mice, but no immunologically detectable fibrinogen was found in whole blood collected from neonates later genotyped as $\mathrm{A} \alpha^{-1-}$. Furthermore, blood collected from these newborns uniformly failed to clot, either spontaneously or when combined with thrombin. In contrast, blood collected from newborns found to carry at least one normal A $\alpha$-chain allele contained easily detectable fibrinogen and clotted promptly in vitro. The definitive test for the importance of maternal fibrinogen in embryonic development, a cross between a $\mathrm{A} \alpha^{-1-}$ breeding pair, could not be used to formally resolve this issue because $\mathrm{A}^{-1-}$ females are unable to carry litters to term irrespective of the genotype of their mates. However, it is clear that maternal fibrinogen is critical for reproduction. Based on the time (gestational day 9 to day 10 ) and location (placental labyrinthine layer) of bleeding events in pregnant $\mathrm{A} \alpha^{-1-}$ mice, it appears that maternal fibrinogen is important for the successful intermingling of embryonic trophoblasts with the maternal vasculature.

The primary sites of hemorrhage in fibrinogen-deficient neonates (i.e., abdomen, skin around the head and neck, and periumbilical region) are also common sites of spontaneous bleeding events in human newborns with acquired or congenital coagulation disorders (Baehner and Strauss 1966; Oski 1982; Montgomery and Scott 1993). The bleeding manifestations (e.g., hemoperito- 
neum, periumbilical hemorrhage, ecchymoses, soft tissue bleeds, gastrointestinal hemorrhage, and epistaxis| and hematological profile of $\mathrm{A \alpha}^{-1-}$ mice are generally comparable to those observed in the rare human congenital disorder, afibrinogenemia (Al-Mondhiry and Ehmann 1994). The particular propensity for intra-abdominal hemorrhage in the human disorder seems to be often the result of splenic rupture (Ehmann and Al-Mondhiry 1994), whereas in mice this appears to be associated with rupture of hepatic hematomas. Differences in abdominal organ positioning and contacts related to biped versus quadriped motion may account for these observations.

Given that afibrinogenemic blood is totally unclottable, it is remarkable that $\mathrm{A \alpha}^{-/-}$mice do not bleed even more frequently (e.g., following periodic rupture of ovulation follicles) and that they manage to control at least some bleeding events. In this regard, it is notable that patients classified as afibrinogenemic often experience fewer spontaneous bleeding events than hemophiliacs (Al-Mondhiry and Ehmann 1994). One possible explanation for these counterintuitive findings is that thrombin generation /which is impaired in hemophiliacs but presumably not impaired in fibrinogen-deficient individuals) results in sufficient platelet activation and platelet plug formation to control some bleeds. However, this view must be reconciled with the fact that platelet aggregation in vitro appears to depend on fibrinogen as the bridging molecule between GPIIb-IIIa on neighboring platelets. One trivial way to integrate these observations is that many patients classified as "afibrinogenemic" based on the standard clinical definition $\mid<1 \%$ of the normal level of plasma fibrinogen) are actually severe cases of hypofibrinogenemia, with significant plateletassociated fibrinogen and platelet aggregation in the standard assays (DeMarco et al. 1986). Because the $\mathrm{A}^{-1-}$ mice appear to be truly afibrinogenemic and lack both clotting function and platelet aggregation potential in vitro, a nontrivial explanation is needed for the ability of these animals to control and survive bleeding events. One hypothesis that stands out is that under the high shear flow conditions of the vasculature one or more ligands for platelet receptors can serve, in the absence of fibrinogen, in establishing some form of platelet plug. GPIIb-IIIa is known to bind many ligands other than fibrinogen, including vitronectin (Thiagarajan and Kelly 1988), fibronectin (Plow et al. 1984), and von Willebrand factor (Ruggeri et al. 1983, Weiss et al. 1989). In addition, platelets have many receptors other than GPIIb-IIIa for common matrix components, and one or more of these could provide a means of controlling bleeding at sites of vascular breaks. However, whatever the level of protection provided by platelets and other factors in fibrinogendeficient mice, it is clearly insufficient to control significant challenges (e.g., a surgical nail-bed injury) that are easily controlled in normal mice.

Fatal spontaneous bleeding events in juvenile and young adult mice appears to be primarily the result of mechanical trauma resulting in the formation and subsequent rupture of hepatic subcapsular hematomas. The trauma hypothesis is supported by the nearly uniform subcapsular location of hepatic lesions and serological data indicating the absence of common mouse pathogens in lesion-bearing mice. Interestingly, mice lacking the key fibrinolytic enzyme, plasminogen, frequently develop subcapsular fibrin deposits (Bugge et al. 1995), consistent with the surface trauma hypothesis for the origin of liver lesions. An important unresolved issue is whether the trauma hypothesis can account for the distinctly superior survival profile of $\mathrm{A}^{-1-}$ mice with a $\mathrm{C} 57 \mathrm{Bl} / 6 \mathrm{~J}$ genetic background relative to those mice with a hybrid 129/CF-1 background. Subcapsular hematomas have been observed in $\mathrm{A}^{-1-}$ mice with both genetic backgrounds, but their relative frequency, size, and tendency to rupture have not yet been formally compared. If the fatal bleeding events observed result principally from mechanical injury, the different survival profiles of $\mathrm{A}^{-1-}$ mice with different genetic backgrounds could reflect some subtle variation in anatomy. Alternatively, differences in the incidence of fatal bleeding could simply reflect a more sedentary lifestyle in $\mathrm{C} 57 \mathrm{Bl} / 6 \mathrm{~J}$ mice relative to 129 /CF-1 mice.

One of the most striking observations made in $\mathrm{A \alpha}^{-1-}$ mice is the unusual organization of cells within hepatic and renal hematomas. The pattern of thick bands of fibroblasts encapsulating blood pools implies that fibrin provides an essential provisional matrix that is critical for the cellular infiltration of these lesions; without this fibrin matrix, responding cells are restricted to the local tissue matrix. This concept is supported by the alignment of histiocytes along the edges of some blood pools and the maintenance of discrete borders even after advanced growth of the encapsulating cells. The ultimate resolution of these lesions as thick fibrotic scars may provide a plausible explanation for the drop in mortality rate in $\mathrm{A} \alpha^{-1-}$ mice beyond 2 months of age. The accumulation of this scar tissue at the liver surface in older mice may protect the liver from further injury or capsule rupture.

It was recently reported that mice lacking plasminogen develop severe spontaneous thombosis but often survive to breeding age and are capable of reproduction (Bugge et al. 1995). Therefore, development of a functional vasculature is possible in the absence of either key coagulation or fibrinolytic components. However, life without an efficient fibrinolytic system is nearly as precarious as life without fibrin(ogen). At an early age, plasminogen-deficient mice develop severe thrombotic lesions in liver, stomach, colon, rectum, lung, and many other tissues (Bugge et al. 1995). These thrombotic lesions are often associated with significant, life-threatening organ damage. Thus, dramatic swings in the hemostatic balance in either direction are compatible with life, but the prospects for long-term survival are diminished considerably even in the absence of significant challenges, such as pregnancy and overt injury.

The fibrinogen-deficient mice generated in this study will provide a valuable in vivo model system for exploring the role of fibrin(ogen) in wound pathophysiology and disease pathogenesis. Becuase this molecule would be expected to play an integral role in the "response to 
Suh et al.

injury" in any tissue and in the context of any challenge, it will be of interest to define the consequences of fibrinogen deficiency on both the initial organization of cells within wound fields and the overall outcome of wound repair in diverse contexts, such as the skin and eye. These mice also provide the means to definitively examine the therapeutic value of different formulations of fibrin sealants (Sierra 1993) in promoting wound repair in various contexts. Finally, these mice provide an opportunity to test long-standing hypotheses that local fibrin deposition participates in a significant way in the progression of common, life-threatening diseases, including atherosclerosis (Bini and Kudryk 1992), sickle cell disease (Francis and Hebbel 1994), and cancer (Dvorak 1986; Costantini and Zacharski 1992; Nagy et al. 1995). These concepts can be definitively tested by simply crossing $\mathrm{A} \alpha^{-1-}$ mice to available transgenic lines that are genetically predisposed to these (Guy et al. 1992; Plump et al. 1992; Zhang et al. 1992; Trudel et al. 1994) and other diseases.

\section{Materials and methods}

Construction of the fibrinogen A $\alpha$-chain targeting vector and generation of transgenic mice

The mouse fibrinogen A $\alpha$-chain gene was isolated from a $129 /$ SvI genomic DNA library (Shull et al. 1992) using a 1.9-kb EcoRI fragment of a mouse fibrinogen A $\alpha$-chain cDNA complementary to sequences in exons 2-5. The organization (Fig. 1B) and the complete nucleotide sequence of the mouse A $\alpha$-chain gene has been established (T.T. Suh, C. Kessler, M.J. Flick, and J.L. Degen, in prep.) and found to be comparable to the rat (Crabtree et al. 1985) and human (Chung et al. 1990) A $\alpha$-chain genes. The targeting vector used to disrupt the fibrinogen $\mathrm{A} \alpha$ chain in ES cells (see Fig. 1A) was constructed using a 4-kb HindIII fragment encompassing exons 1-3 (Fig. 1B) subcloned into a modified Bluescript plasmid (Stratagene) lacking the polylinker BamHI site. A unique Ball site located in exon 1 was converted to a unique BamHI site by incorporation of a synthetic linker. A 6-kb minigene cassette encoding human HPRT (Reid et al. 1990) was subsequently introduced into the $B a m H I$ site in a trancriptional orientation opposite to that of the A $\alpha$-chain gene. The targeting vector was then further modified by incorporation of a 2 -kb ClaI cassette encoding herpes simplex virus thymidine $\mathrm{ki}$ nase (HSV-tk) to provide a means of selection against cells that randomly insert the targeting vector into the genome (Mansour et al. 1988). Vector-free insert DNA was prepared from the targeting vector plasmid by digestion with SalI and SstII and electrophoretic fractionation on an agarose gel. The targeting vector was introduced into the HPRT-deficient ES cell line (E14TG2a; Hooper et al. 1987) by electroporation, and stable transfectants were selected as described previously (Bugge et al. 1995). Clonal isolates were initially screened for appropriately targeted cells by Southern blot hybridization analysis of genomic DNA extracts using one diagnostic restriction enzyme, PvulI, and hybridization probe A 1500 -bp HindIII-BamHI fragment complementary to sequences contained within the targeting vector; see Fig. 1B). Incorporation of the targeting vector into the A $\alpha$-chain gene was confirmed using three diagnostic restriction enzymes, PvuII, BalI, and PstI, and hybridization probe B 4430 -bp PvulIHindIII fragment complementary to a $5^{\prime}$-flanking sequence of the $A \alpha$-chain gene that was not included in the $A \alpha$-chain targeting vector; see Fig. 1B). Additional confirmation that target- ing vector sequences were incorporated into the endogenous $\mathrm{A} \alpha$-chain gene was obtained by PCR analysis of genomic DNA using the diagnostic primers $a$ and $c$ (see Fig. 1B) that yield a predicted 690-bp amplification product only with the appropriately targeted A $\alpha$-chain allele as a template. Primer a $5^{\prime}$ AGCTAGGACTGTGGATCGTGGCATTG-3') is complementary to a sequence upstream of the $A \alpha$-chain gene that was not included in the targeting vector. Primer $c\left(5^{\prime}\right.$-TATTACCAGTGAATCTTTGTCAGCAG-3') is complementary to a sequence in the HPRT minigene cassette. The suitability of each DNA preparation as a template for PCR was demonstrated using primers $b$ and $c$ that yield a 190-bp amplification product independent of the site of transgene integration. Primer $b\left(5^{\prime}\right.$-GCT TCAGCTCCAGTTCTCCTCATGAGCCAT-3' $)$ is complementary to a sequence in the first exon of the $A \alpha$-chain gene. Correctly targeted ES cells were microinjected into the blastocoel cavity of $\mathrm{C} 57 \mathrm{Bl} / 6 \mathrm{~J}$ blastocysts and implanted into pseudopregnant females (Li et al. 1994). Chimeric males generated were bred to either $\mathrm{C} 57 \mathrm{Bl} / 6 \mathrm{~J}$ or CF-1 females to generate heterozygous, $\mathrm{A} \alpha^{+/-}$offspring. $\mathrm{A} \alpha^{+/-}$mice /maintained in separate CF-1 or C $57 \mathrm{Bl} / 6$ J backgrounds) were then crossed to generate $\mathrm{A} \alpha^{-1-}$ progeny.

\section{Genotype analysis}

Genotypes of mice were established using tail biopsy DNA / $\mathrm{Li}$ et al. 1994) and either Southern blot hybridization or PCR analyses. In the Southern blot assay, Pvull digests of genomic DNAs were analyzed as indicated above. In the PCR assays, mice carrying one (or more) targeted A $\alpha$-chain allele $(s)$ were identified using reaction mixtures containing either primer set $a$ and $c$ (described above) or primer set $d$ and $e$ that generates a 660-bp amplification product. Like primer $a$, primer $d\left(5^{\prime}\right.$-GCAGCTACTGTCTTGACCTCTGGCTGGAGG- $\left.3^{\prime}\right)$ is complementary to a sequence upstream of the $A \alpha$-chain gene that was not included in the targeting vector. Primer $e\left(5^{\prime}\right.$-TATTACCAGTGAATCTTTGTCAGCAGTTCCC-3' is complementary to the HPRT minigene cassette and is essentially an extended form of primer c. Mice carrying one (or more) wild-type A $\alpha$-chain allele(s) were identified using reaction mixtures containing primer set $a$ and $f$ or primer set $d$ and $g$ that generates amplification products of $910 \mathrm{bp}$ or $840 \mathrm{bp}$, respectively. Primers $f$ $\left(5^{\prime}\right.$-AACAATTTTCTAGTTGCGGGTCA-3') and $g\left(5^{\prime}\right.$-TGCTGGATCAATCCCCAGCAACCGTGAGAG-3') are complementary to different sequences located within the first intron of the A $\alpha$-chain gene.

\section{Northern blot analysis}

Total RNA was prepared from total nucleic acid extracts as described previously (Degen et al. 1985). Twenty-microgram samples were fractionated by electrophoresis on denaturing agarose gels, transferred to nitrocellulose filters, and hybridized to ${ }^{32} \mathrm{P}$-labeled fibrinogen or plasminogen probes $\left(2 \times 10^{8}\right.$ to $3 \times 10^{8}$ $\mathrm{cpm} / \mu \mathrm{g})$ (Bell et al. 1990). The fibrinogen A $\alpha$-chain probe was prepared (Feinberg and Vogelstein 1983) from a 446-bp EcoRI$E c o$ RV fragment of a mouse A $\alpha$-chain cDNA that encompasses 129 nucleotides of exon 2, exons 3 and 4 , and 12 nucleotides of exon 5 of the $A \alpha$-chain gene. The fibrinogen $B \beta$-chain probe was prepared from an $\sim 390$-bp BamHI-EcoRI fragment of a mouse cDNA encompassing 219 nucleotides of exon 8 and adjacent 3 '-noncoding sequences. The fibrinogen $\gamma$ chain probe was prepared from an $\sim 190$-bp NsiI-BamHI fragment of the mouse $(129 / \mathrm{SvI}) \gamma$-chain gene encompassing a small portion of intron 8 and 163 nucleotides of exon 9 (T.T. Suh, C. Kessler, M.J. Flick, 
and J.L. Degen, in prep.). The plasminogen probe was prepared from a 2-kb EcoRI fragment of the mouse plasminogen cDNA MP33B (Degen et al. 1990).

\section{Hematological analysis and bleeding time measurements}

The blood of adult mice was collected from the inferior vena cava of anesthetized adult mice into one-tenth volume of 0.129 M sodium citrate anticoagulant as described previously (Bugge et al. 1995). Blood cell counts and hematocrit were determined using a Technicon $\mathrm{H}-1$ blood cell analyzer. Plasma was prepared by centrifugation at $2500 \mathrm{~g}$ for $10 \mathrm{~min}$ at room temperature. Plasma thrombin times were measured by combining in glass tubes $70 \mu \mathrm{l}$ plasma samples (preincubated at $37^{\circ} \mathrm{C}$ ) with $70 \mu \mathrm{l}$ of $20 \mathrm{U} / \mathrm{ml}$ bovine thrombin (Pacific Hemostasis) in phosphatebuffered saline. The spontaneous whole blood clotting times of neonates were determined by monitoring clot formation in 10$\mu \mathrm{l}$ blood samples (collected without anticoagulant from decapitated mice) placed on glass slides. The whole blood thrombin times of neonates were determined by monitoring clot formation in $10-\mu$ l blood samples following addition of $10 \mu \mathrm{l}$ of 20 $\mathrm{U} / \mathrm{ml}$ bovine thrombin. Bleeding time was measured in adult mice anesthetized with $0.1 \mathrm{ml}$ per $30 \mathrm{~g}$ body weight of ketamine/xylazine/acepromazine $(4: 1: 1)$. Bleeding was initiated by amputation of the tip of the fifth digit immediately behind the nail bed. The bleeding time was established while gently blotting emerging blood with Whatman 3MM paper every 5-10 sec.

\section{Immunological analysis of whole blood and} plasma fibrinogen

Fibrinogen in whole blood samples of neonates was qualitatively assayed by Western blot analysis. Samples of whole blood $(10 \mu \mathrm{l})$ were collected from decapitated mice and dispensed immediately into an equal volume of twofold concentrated polyacrylamide gel sample buffer $[1 \times$ sample buffer $=80 \mathrm{~mm}$ Tris$\mathrm{HCl}(\mathrm{pH} 6.8)$ containing $2 \%$ SDS, $0.7 \mathrm{~m} \beta$-mercaptoethanol, $0.004 \%$ bromophenol blue, and $10 \%$ glycerol]. The samples were heated to $100^{\circ} \mathrm{C}$ for $5 \mathrm{~min}$ and serially diluted in sample buffer to $0.1 \mu \mathrm{l}, 0.05 \mu \mathrm{l}$, and $0.025 \mu \mathrm{l}$ of whole blood per $20 \mu \mathrm{l}$. Blood proteins were fractionated by SDS-polyacrylamide gel electrophoresis, transferred to Immobilon-P (Millipore), and processed for immunodetection of the three fibrinogen polypeptide chains as described previously (Heckel et al. 1990) except that bound biotin-peroxidase conjugate was detected by autoradiography using the ECL chemiluminescence system (Amersham) and Kodak AR X-ray film. Normal adult mouse plasma $(0.1 \mu \mathrm{l})$ and purified rat fibrinogen (20 and $40 \mathrm{ng}$ ) were analyzed in parallel as positive controls.

Fibrinogen was measured quantitatively in adult mouse plasma samples by fibrinogen-specific enzyme-linked immunosorbent assay (ELISA) using the Asserachrom-Fibrinogen system (Diagnostica Stago) together with a purified mouse fibrinogen standard.

\section{Histological analysis and electron microscopy}

Tissues collected for histological analyses were placed into zinc-formalin fixative (U.S. Biotex), processed into paraffin, sectioned, and stained with hematoxylin/eosin by standard techniques. Fibrinogen-related antigen within liver sections was immunostained using a rabbit antiserum raised against rat fibrinogen (kindly provided by R.F. Doolittle, University of California, San Diegol and the Vectastain Elite ABC system (Vector) with nickel-enhanced diaminobenzidine stain. Tissues for electron microscopy were fixed with $3 \%$ glutaraldehyde in
Millonig's buffer, postfixed in osmium tetroxide, and embedded in LX-112 (Ladd). Silver sections (90 $\AA$ ) were examined using a Phillips 400 transmission electron microscope.

\section{Platelet aggregation analysis}

Whole blood (generally $900 \mu \mathrm{l}$ per adult mouse) was drawn directly into citrate anticoagulant from the inferior vena cava of anesthetized mice (see above). Blood samples were centrifuged at $\sim 600 \mathrm{~g}$ for $25 \mathrm{~min}$ at room temperature, and a platelet-rich plasma (PRP) fraction was collected and transferred to fresh plastic tubes. The remaining portion of each sample was then centrifuged at $\sim 2500 \mathrm{~g}$ for $10 \mathrm{~min}$ to generate platelet-poor plasma (PPP). The platelet count in PRP samples was determined using a Technicon $\mathrm{H}-1$ analyzer. Aggregation assays were performed at $37^{\circ} \mathrm{C}$ using a ChronoLog 560 dual-channel aggregometer. Aggregation was initiated by the addition of either 25 $\mu \mathrm{l}$ of $100 \mu \mathrm{M}$ ADP (Sigma), $25 \mu \mathrm{l}$ of $100 \mathrm{U} / \mu \mathrm{l}$ bovine thrombin (Pacific Hemostasis), or $50 \mu \mathrm{l}$ of $100 \mu \mathrm{g} / \mathrm{ml}$ equine collagen (Helena) to $225 \mu \mathrm{l}$ of platelet suspensions $(200,000-300,000$ platelets $/ \mu l)$.

\section{Acknowledgments}

We thank Drs. Sandra Degen, Eric Sandgren, Mary Jo Danton, Earl Davie, and Russell Doolittle for their encouragement and advice. We wish to thank Drs. David Witte and Bruce Aronow for their provocative insights, help in establishing the age of developing embryos, and assistance with photography. We also thank Matt Flick, Ann Becker, and Jean Snyder for their assistance in maintenance of the mouse colony, hematological analyses, and histological analyses, respectively. This work was supported by grants from the National Institutes of Health to J.L.D. (HL47826), S.S.P. (HD29599), and D.I.S. (HL02768). Additional support was provided by the National American Heart Association (with funds contributed by the AHA Ohio affiliate) (921103) (J.L.D.). This study was done during the tenure of an Established Investigatorship (J.L.D.) from the American Heart Association (93002570). T.T.S. was supported by a fellowship from the University of Cincinnati Medical Science Scholars Program. K.H. was supported by a fellowship from the Danish Medical Research Council.

The publication costs of this article were defrayed in part by payment of page charges. This article must therefore be hereby marked "advertisement" in accordance with 18 USC section 1734 solely to indicate this fact.

\section{References}

Al-Mondhiry, H. and W.C. Ehmann. 1994. Congenital afibrinogenemia. Am. I. Hematol. 46: 343-347.

Altieri, D.C., P.M. Mannucci, and A.M. Capitanio. 1986. Binding of fibrinogen to human monocytes. I. Clin. Invest. 78: $968-976$

Altieri, D.C., J. Plescia, and E.F. Plow. 1993. The structural motif glycine 190-valine 202 of the fibrinogen $\gamma$ chain interacts with $\mathrm{CD} 1 \mathrm{lb} / \mathrm{CD} 18$ integrin $\left(\alpha_{M} \beta_{2}, M a c-1\right)$ and promotes leukocyte adhesion. J. Biol. Chem. 268: 1847-1853.

Baehner, R.L., and H.S. Strauss. 1966. Hemophilia in the first year of life. N. Engl. J. Med. 275: 524-528.

Bell, S.M., R.W. Brackenbury, N.D. Leslie, and J.L. Degen. 1990. Plasminogen activator gene expression is induced by the src oncogene product and tumor promoters. J. Biol. Chem. 265: 1333-1338.

Bennett, J.S. 1991. Integrin structure and function in hemostasis and thrombosis. Ann. N.Y. Acad. Sci. 614: 214-228. 
Bini, A. and B. Kudryk. 1992. Fibrin and its derivatives in the normal and diseased vessel wall. Ann. N.Y. Acad. Sci. 667: 112-126.

Brown, L.F., N. Lanir, J. McDonagh, K. Tognazzi, A.M. Dvorak, and H.F. Dvorak. 1993. Fibroblast migration in fibrin gel matrices. Am. J. Pathol. 142: 273-283.

Bugge, T.H., M.J. Flick, C.C. Daugherty, and J.L. Degen. 1995. Plasminogen deficiency causes severe thrombosis but is compatible with development and reproduction. Genes \& Dev. 9: 794-807.

Chung, D.W. and A. Ichinose. 1995. Hereditary disorders of fibrinogen and factor XIII. In The metabolic and molecular bases of inherited disease, 7th ed. (ed. C.R. Scriver, A.L. Beaudet, W.S. Sly, and D. Valle), pp. 3223-3240. McGrawHill, New York.

Chung, D.W., J.E. Harris, and E.W. Davie. 1990. Nucleotide sequence of the three genes coding for human fibrinogen. In Fibrinogen, thrombosis, coagulation, and fibrinolysis led. C.Y. Liu and S. Chien), pp. 39-48. Plenum Press, New York.

Collen, D. and H.R. Lijnen. 1994. Fibrinolysis and the control of hemostasis. In The molecular basis of blood diseases, 2 nd ed. (ed. G.S. Stamatoyannopoulos, A.W. Nienhuis, P.W. Majerus, and H. Varmus), pp. 725-752. W.B. Saunders Co., Philadelphia, PA.

Colvin, R.B., R.A. Johnson, M.C. Mihm Jr., and H.F. Dvorak. 1973. Role of the clotting system in cell-mediated hypersensitivity. Fibrin deposition in delayed skin reactions in man. I. Exp. Med. 138: 686 698.

Costantini, V. and L.R. Zacharski. 1992. The role of fibrin in tumor cell metastasis. Cancer Metastasis Rev. 11: 283-290.

Crabtree, G.R. and J.A. Kant. 1982. Coordinate accumulation of the mRNA for the $\alpha, \beta$, and $\gamma$ chains of rat fibrinogen following defibrination. I. Biol. Chem. 257: 7277-7279.

Crabtree, G.R., C.M. Comeau, D.M. Fowlkes, A.J. Fornace Jr., I.D. Malley, and J.A. Kant. 1985. Evolution and structure of the fibrinogen genes. Random insertion of introns or selective loss? I. Mol. Biol. 185: 1-19.

Cross, J.C., Werb, Z., and S.J. Fisher. 1994. Implantation and the placenta: Key pieces of the developmental puzzle. Science 266: $1508-1518$

Dahlbäck, B. and J. Stenflo. 1994. The protein C anticoagulant system. In The molecular basis of blood diseases, 2 nd ed. led. G.S. Stamatoyannopoulos, A.W. Nienhuis, P.W. Majerus, and H. Varmus), pp. 599-627. W.B. Saunders Co., Philadelphia, PA.

Davie E.W., K. Fujikawa, and W. Kisiel. 1991. The coagulation cascade: Initiation, maintenance, and regulation. Biochem isty 30: 10363-10370.

Degen, J.L., R.D. Estensen, Y. Nagamine, and E. Reich. 1985. Induction and desensitization of plasminogen activator gene expression by tumor promoters. J. Biol. Chem. 260: 12426 12433.

Degen, S.J.F., S.M. Bell, L.A. Schaefer, and R.W. Elliott. 1990. Characterization of the cDNA coding for mouse plasminogen and localization of the gene to mouse chromosome 17 Genomics 8: 49-61.

Dejana, E., L.R. Languino, N. Polentarutti, G. Balconi, I.J. Ryckewaert, M.J. Larrieu, M.B. Donati, A. Mantovani, and G. Marguerie. 1985. Interaction between fibrinogen and cultured endothelial cells: Induction of migration and specific binding. J. Clin. Invest. 75: 11-18.

DeMarco, L., A. Girolami, T.S. Zimmerman, and Z.M. Ruggeri. 1986. von Willebrand factor interaction with the glycopro tein IIb/IIIa complex. Its role in platelet function as demonstrated in patients with congenital afibrinogenemia. $/$. Clin. Invest. 77: 1272-1277.
Donaldson, D.J., I.T. Mahan, D.L. Amrani, D.H. Farrell, and J.H. Sobel. 1994. Further studies on the interaction of migrating keratinocytes with fibrinogen. Cell Adhes. Commun. 2: 299-308.

Doolittle, R.F. 1994. The molecular biology of fibrin. In The molecular basis of blood diseases (ed. G.S. Stamatoyannopoulos, A.W. Nienhuis, P.W. Majerus, and H. Varmus|, pp. 701-723. W.B. Saunders Co., Philadelphia, PA.

Dvorak, H.F. 1986. Tumors: Wounds that do not heal. Similarities between tumor stroma generation and wound healing. N. Engl. I. Med. 315: 1650-1659.

Dvorak, H.F., J.A. Nagy, B. Berse, L.F. Brown, K.-T. Yeo, T.-K. Yeo, A.M. Dvorak, L. Van De Water, T.M. Siousat, and D.R. Senger. 1992. Vascular permeability factor, fibrin, and the pathogenesis of tumor stroma formation. Ann. N.Y. Acad. Sci. 667: 101-111.

Ehmann, W.C. and H. Al-Mondhiry. 1994. Congenital afibrinogenemia and splenic rupture. Am. I. Med. 96: 92-94.

Esmon, C.T. 1993. Cell mediated events that control blood coagulation and vascular injury. Annu. Rev. Cell Biol. 9: 1-26.

Feinberg, A.P. and B. Vogelstein. 1983. A technique for radiolabeling DNA restriction endonuclease fragments to high specific activity. Anal. Biochem. 132: 6-13.

Francis, R.B. and R.P. Hebbel. 1994. Hemostasis. In Sickle cell disease: Basic principles and clinical practice (ed. S.H. Embury, R.P. Hebbel, N. Mohandas, and M.H. Steinbergl, pp. 299-310. Raven Press, New York.

Guy, C.T., R.D. Cardiff, and W.J. Muller. 1992. Induction of mammary tumors by expression of polyomavirus middle $T$ oncogene: A transgenic model for metastatic disease. Mol. Cell. Biol. 12: 954-961.

Heckel, J.L., E.P. Sandgren, J.L. Degen, R.D. Palmiter, and R.L. Brinster. 1990. Neonatal bleeding in transgenic mice expressing urokinase-type plasminogen activator. Cell 62: $447-456$

Hooper, M.L., K. Hardy, A. Handyside, S. Hunter, and M. Monk. 1987. HPRT-deficient (Lesch-Nyhan) mouse embryos derived from germline colonization by cultured cells. Nature 326: 292-295.

Huang, S., E.R. Mulvihill, D.H. Farrell, C.W. Chung, and E.W Davie. 1993. Biosynthesis of human fibrinogen. Subunit interactions and potential intermediates in assembly. J. Biol. Chem. 268: 8919-8926.

Katagiri, Y., T. Hiroyama, N. Akamatsu, H. Suzuki, H. Yamazaki, and K. Tanoue. 1995. Involvement of $\alpha_{\mathrm{V}} \beta_{3}$ integrin in mediating fibrin gel retraction. I. Biol. Chem. 270: 17851790.

Languino, L.R., A. Duperray, K.J. Joganic, M. Fornaro, G.B. Thornton, and D.C. Altieri. 1995. Regulation of leukocyteendothelial interaction and leukocyte transendothelial migration by intercellular adhesion molecule 1-fibrinogen recognition. Proc. Natl. Acad. Sci. 92: 1505-1509.

Li, H., D.P. Witte, W.W. Branford, B.J. Aronow, M. Weinstein, S. Kaur, S. Wert, G. Singh, C.M. Schreiner, J.A. Whitsett, W.J. Scott, and S.S. Potter 1994. Gsh-4 encodes a LIM-type homeodomain, is in the developing nervous system and is required for early postnatal survival. EMBO I. 13: 2876-2885.

Majerus, P.W. 1994. Platelets. In The molecular basis of blood diseases (ed. G.S. Stamatoyannopoulos, A.W. Nienhuis, P.W. Majerus, and H. Varmus), pp. 753-785. W.B. Saunders Co., Philadelphia, PA.

Mansour, S.L., K.R. Thomas, and M.R. Capecchi. 1988. Disruption of the proto-oncogene int- 2 in mouse embryo-derived stem cells: A general strategy for targeting mutations to nonselectable genes. Nature 336: 348-352.

Marder,V.J., D.I. Feinstein, C.W. Francis, and R.W. Colman. 
1994. Consumptive thrombohemorrhagic disorders. In $\mathrm{He}$ mostasis and thrombosis, basic principles and clinical practices (ed. R.W. Colman, J. Hirsh. V.J. Marder, and E.W. Salzman), pp. 1023-1063. J.B. Lipponcott, Philadelphia, PA.

McRitchie, D.I., M.J. Girotti, M.F.X. Glynn, J.M. Goldberg, and O.D. Rotstein. 1991. Effect of systemic fibrinogen depletion on intraabdominal abscess formation. I. Lab. Clin. Med. 118: $48-55$.

Montgomery, R.R. and J.P. Scott. 1993. Hemostasis: Diseases of the fluid phase. In Hematology of infancy and childhood (ed. D.G. Nathan and F.A. Oski), pp. 1605-1650. W.B. Saunders Co., Philadelphia, PA.

Nagy, J.A., E.S. Morgan, K.T. Herzberg, E.J. Manseau, A.M. Dvorak, and H.F. Dvorak. 1995. Pathogenesis of ascites tumor growth: Angiogenesis, vascular remodeling, and stroma formation in the peritoneal lining. Cancer Res. 55: 376-385.

Naito, M., C. Funaki, T. Hayashi, K. Yamada, K. Asai, N. Yoshimine, and F. Kuzuya. 1992. Substrate-bound fibrinogen, fibrin and other cell attachment-promoting proteins as a scaffold for cultured vascular smooth muscle cells. Ath erosclerosis 96: 227-234.

Oski, F.A. 1982. Blood coagulation disorders in the newborn. In Hematologic problems in the newborn (ed. F.A. Oski and J.L. Naiman), pp. 137-174. W.B. Saunders Co., Philadelphia, PA.

Plow, E.F. and T.S. Edgington. 1986. Lymphocyte suppressive peptides from fibrinogen are derived predominantly from the A $\alpha$ chain. J. Immunol. 137: 1910-1915.

Plow, E.F., A.H. Srouji, D. Meyer, G.A. Marguerie, and M.H. Ginsberg. 1984. Evidence that three adhesive proteins interact with a common recognition site on activated platelets. $J$. Biol. Chem. 259: 5385-5391.

Plump, A.S., J.D. Smith, T. Hayek, K. Aatlto-Setala, A. Walsh, J.G. Verstuyft, E.M. Rubin, and J.L. Breslow. 1992. Severe hypercholesterolemia and atherosclerosis in apolipoprotein E-deficient mice created by homologous recombination in ES cells. Cell 71: 343-353.

Reid, L.H., R.G. Gregg, O. Smithies, B.H. Koller. 1990. Regulatory elements in the introns of the human HPRT gene are necessary for its expression in embryonic stem cells. Proc. Natl. Acad. Sci. 87: 4299-4303.

Roy, S.N., R. Procyk, B.J. Kudryk, and C.M. Redman. 1991. Assembly and secretion of recombinant human fibrinogen. $I$. Biol. Chem. 266: 4758-4763.

Ruggeri, Z.M., L. DeMarco, L. Gatti, R. Bader, R.R. Montgomery. 1983. Platelets have more than one binding site for von Willebrand factor. J. Clin. Invest. 72: 1-12.

Sadler, J.E. and E.W. Davie. 1994. Hemophilia A, hemophilia B, and von Willebrand disease. In The molecular basis of blood diseases (ed. G.S. Stamatoyannopoulos, A.W. Nienhuis, P.W. Majerus, and H. Varmus|, pp. 657-700. W.B. Saunders Co., Philadelphia, PA.

Sherman, L.A. and J. Lee. 1977. Specific binding of soluble fibrin to macrophages. I. Exp. Med. 145: 76-85.

Shull, M.M., I. Ormsby, A.B. Kier, S. Pawlowski, R.J. Diebold, M. Yin, R. Allen, C. Sidman, G. Proetzel, D. Calvin, N. Annunziata, and T. Doetschman. 1992. Targeted disruption of the mouse transforming growth factor- $\beta 1$ gene results in multifocal inflammatory disease. Nature 359: 693-699.

Sierra, D.H. 1993. Fibrin sealant adhesive systems: A review of their chemistry, material properties and clinical applications. J. Biomater. Appl. 7: 309-352.

Simon, D.I., A.M. Ezratty, S.A. Francis, H. Rennke, and J. Loscalzo. 1993. Fibrin(ogen) is internalized and degraded by activated human monocytoid cells via Mac-1 (CD11b-CD18): A nonplasmin fibrinolytic pathway. Blood 82: 2414-2422.

Skogen, W.F., R.M. Senoir, G.L. Griffin, and G.D. Wilner. 1988.
Fibrinogen-derived peptide $\mathrm{Bbl}-42$ is a multidomained neutrophil chemoattractant. Blood 71: 1475-1479.

Tang, L. and J.W. Eaton. 1993. Fibrin(ogen) mediates acute inflammation reponses to biomaterials. I. Exp. Med. 178: $2147-2156$.

Thiagarajan, P. and K.L. Kelly. 1988. Exposure of binding sites for vitronectin on platelets following stimulation. J. Biol. Chem. 263: 3035-3038.

Trudel, M., M.E. DePaepe, N. Chrétien, N. Saadane, J. Jacmain, M. Sorette, T. Hoang, and Y. Beuzard. 1994. Sickle cell disease in transgenic SAD mice. Blood 84: 3189-3197.

Wehinger, H., O. Klinge, E. Alexandrakis, J. Schurmann, J. Witt, and H.H. Seydewitz. 1983. Hereditary hypofibrinogenemia with fibrinogen storage in the liver. Eur. J. Pediatr. 141: 109112.

Weiss, H.J., J. Hawiger, Z.M. Ruggeri, V.T. Turitto, P. Thiagarajan, and T. Hoffmann. 1989. Fibrinogen-independent platelet adhesion and thrombus formation on subendothelium mediated by glycoprotein IIb-IIIa complex at high shear rate. I. Clin. Invest. 83: 288-297.

Wright, S.D., J.S. Weitz, A.J. Huang, S.M. Levin, S.C. Silverstein, and J.D. Leike. 1983. Complement receptor type three (CD11b/CD18) of human polymorphonuclear leukocytes recognizes fibrinogen. Proc. Natl. Acad. Sci. 85: 7734-7738.

Zhang, S.H., R.L. Reddick, J.A. Piedrahita, and N. Maeda. 1992. Spontaneous hypercholesterolemia and arterial lesions in mice lacking apolipoprotein E. Science 258: 468-471. 


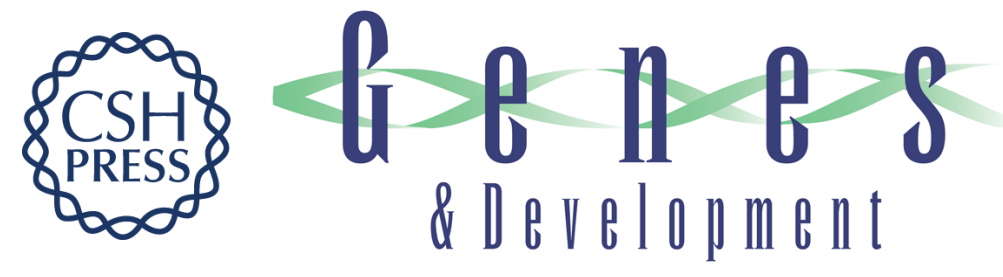

\section{Resolution of spontaneous bleeding events but failure of pregnancy in fibrinogen-deficient mice.}

T T Suh, K Holmbäck, N J Jensen, et al.

Genes Dev. 1995, 9:

Access the most recent version at doi:10.1101/gad.9.16.2020

References This article cites 54 articles, 22 of which can be accessed free at: http://genesdev.cshlp.org/content/9/16/2020.full.html\#ref-list-1

License

Email Alerting Receive free email alerts when new articles cite this article - sign up in the box at the top Service right corner of the article or click here.

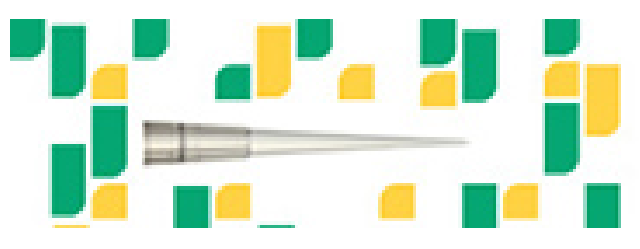

Focused on your science. 